\title{
ॠUSES Exs
}

Prepared in cooperation with the City of Champaign, Illinois, the City of Urbana, Illinois, and the University of Illinois at Urbana-Champaign

\section{Using Observed Postconstruction Peak Discharges to Evaluate a Hydrologic and Hydraulic Design Model, Boneyard Creek, Champaign and Urbana, Illinois}

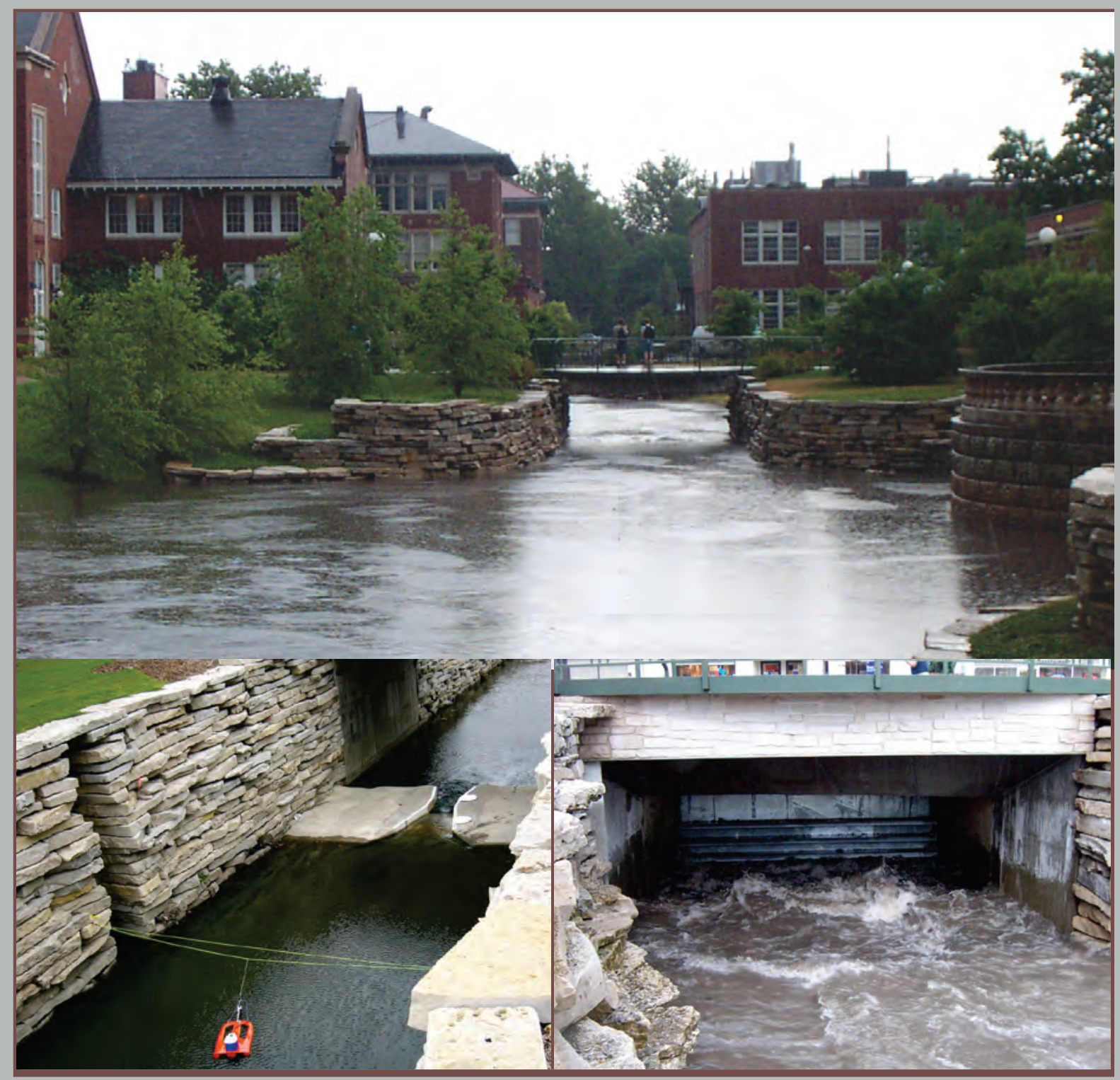

Scientific Investigations Report 2011-5176

U.S. Department of the Interior

U.S. Geological Survey 
Cover. Photograph at the top shows Boneyard Creek flowing through campus of the University of Illinois at Urbana-Champaign during the storm event of June 26, 2007 (photograph by Anthony Spencer, USGS Illinois Water Science Center). Photograph at lower right shows Boneyard Creek emerging from underneath a flow restrictor at Wright Street in Champaign, Illinois, during the storm event of June 26, 2007 (photograph by Anthony Spencer, USGS Illinois Water Science Center). Photograph at lower left shows an acoustic Doppler current profiler on a moving boat upstream from the Parshall flume at USGS streamgage 03337000 (Boneyard Creek at Urbana, III.) on December 3, 2003 (photograph by Kevin K. Johnson, USGS Illinois Water Science Center). 


\section{Using Observed Postconstruction Peak Discharges to Evaluate a Hydrologic and Hydraulic Design Model, Boneyard Creek, Champaign and Urbana, Illinois}

By Thomas M. Over, David T. Soong, and Robert R. Holmes, Jr.

Prepared in cooperation with the City of Champaign, Illinois, the City of Urbana, Illinois, and the University of Illinois at Urbana-Champaign

Scientific Investigations Report 2011-5176 


\title{
U.S. Department of the Interior \\ KEN SALAZAR, Secretary \\ U.S. Geological Survey \\ Marcia K. McNutt, Director
}

\author{
U.S. Geological Survey, Reston, Virginia: 2011
}

For more information on the USGS - the Federal source for science about the Earth, its natural and living resources, natural hazards, and the environment, visit http://www.usgs.gov or call 1-888-ASK-USGS.

For an overview of USGS information products, including maps, imagery, and publications, visit http://www.usgs.gov/pubprod

To order this and other USGS information products, visit http://store.usgs.gov

Any use of trade, product, or firm names is for descriptive purposes only and does not imply endorsement by the U.S. Government.

Although this report is in the public domain, permission must be secured from the individual copyright owners to reproduce any copyrighted materials contained within this report.

Suggested citation:

Over, T.M., Soong, D.T., and Holmes, Jr., R.R., 2011, Using observed postconstruction peak discharges to evaluate a hydrologic and hydraulic design model, Boneyard Creek, Champaign and Urbana, Illinois: U.S. Geological Survey Scientific Investigations Report 2011-5176, 37 p. 


\section{Contents}

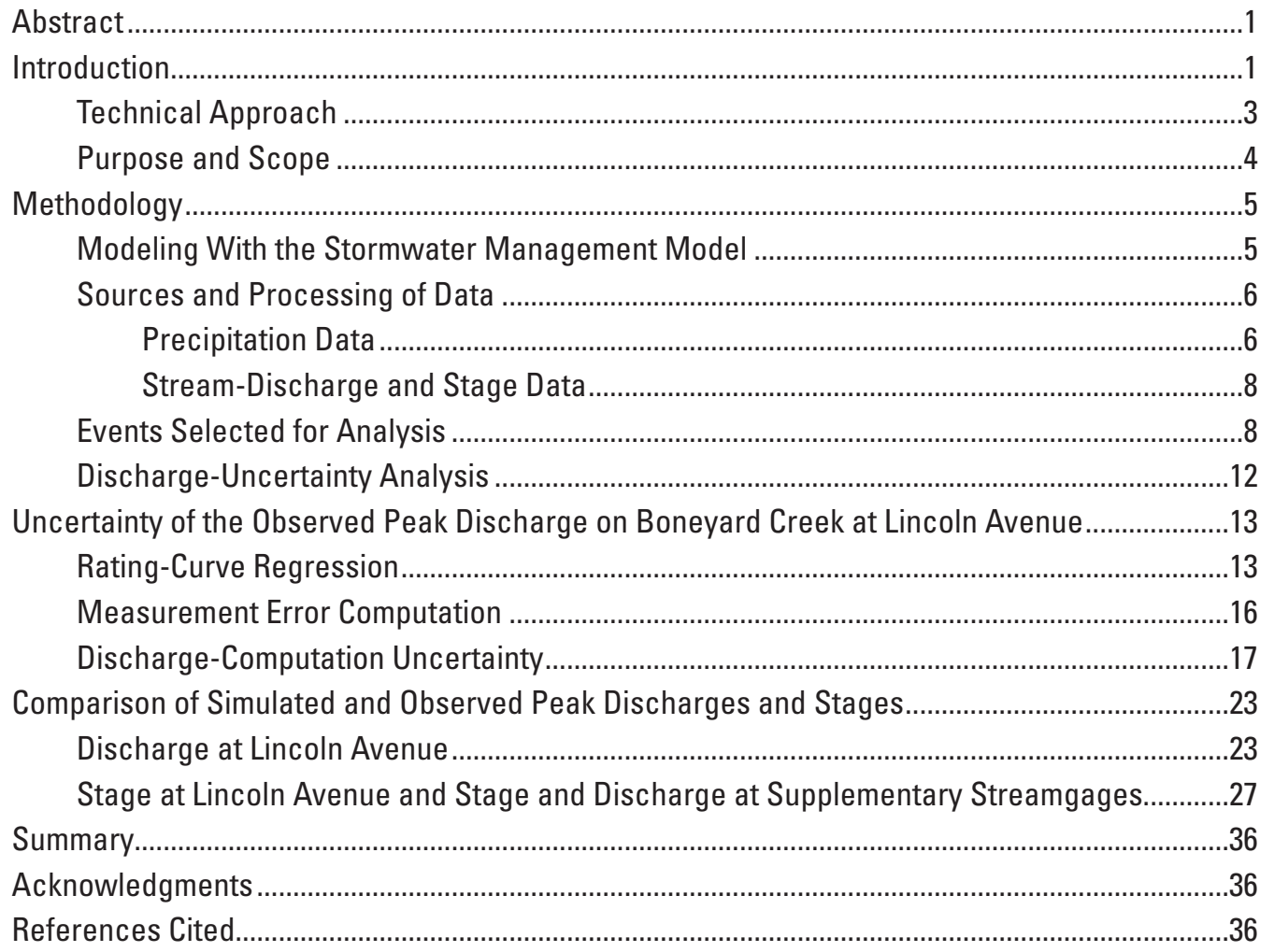

\section{Figures}

1. Map showing Boneyard Creek watershed in Champaign-Urbana, III., and locations of flood-control improvements, U.S. Geological Survey (USGS) rain gages and streamgages

2. Map showing example of Thiessen polygons covering subbasins in the Boneyard Creek Stormwater Management Model (SWMM)

3. Graph showing stage-discharge ratings used for USGS streamgage 03337100 (Boneyard Creek at Lincoln Avenue, Urbana, III.), water years 2002 through 2009...........9

4. Graph showing computation of alternative estimates of peak discharge for the June 26, 2007, high-flow event at USGS streamgage 03337100 (Boneyard Creek at Lincoln Avenue, Urbana, III.).

5. Graph showing stage-discharge rating-curve regression for USGS streamgage 03337100 (Boneyard Creek at Lincoln Avenue, Urbana, III.) using measurements obtained between June 2003 and September 2009 when the depth of flow was greater than 5 feet (gage height greater than 12 feet). $A$, Scatterplot of data and fitted line. $B$, Residuals as a function of time 
6. Graph showing stage-discharge rating-curve regression for USGS streamgage station 03337100 (Boneyard Creek at Lincoln Avenue, Urbana, III.) using measurements obtained during water years 2005 through 2009 when the depth of flow was greater than 1 foot (gage height greater than 8 feet). $A$, Scatterplot of data and fitted line. $B$, Residuals as a function of time.

7. Graph showing components of uncertainty of computed discharge as a function of discharge for USGS streamgage 03337100 (Boneyard Creek at Lincoln Avenue, Urbana, III.), using measurements obtained from June 2003 through September 2009 when the depth of flow was greater than 5 feet. $A$, Measurement error of 5 percent. $B$, Measurement error of 7.5 percent.

8. Graph showing uncertainty of computed discharge expressed as a standard deviation at USGS streamgage 03337100 (Boneyard Creek at Lincoln Avenue, Urbana, III.), using measurements obtained from June 2003 through September 2009 when the depth of flow was greater than 5 feet...

9. Graph showing approximate 95-percent confidence interval of instantaneous discharge uncertainty at USGS streamgage station 03337100 (Boneyard Creek at Lincoln Avenue, Urbana, III.), using measurements obtained from June 2003 through September 2009 when the depth of flow was greater than 5 feet.

10. Graph showing peak discharges from SWMM4 simulations and observed values with estimated 95-percent confidence intervals for USGS streamgage 03337100 (Boneyard Creek at Lincoln Avenue, Urbana, III.), for storm events analyzed during this study......

11. Graph showing peak stages from SWMM4 simulations and observed values at USGS streamgage 03337100 (Boneyard Creek at Lincoln Avenue, Urbana, III.) for storm events analyzed during this study.

12. Graph showing peak discharges from SWMM4 simulations and observed values at USGS streamgage 03337000 (Boneyard Creek at Urbana, III.) on the campus of the University of Illinois at Urbana-Champaign for storm events analyzed during this study.

13. Graph showing peak stages from SWMM4 simulations and observed values at USGS gaging station 03337000 (Boneyard Creek at Urbana, III.) on the campus of the University of Illinois at Urbana-Champaign, for storm events analyzed for this study.

14. Graph showing peak stages from SWMM4 simulations and observed values at USGS streamgage 03337250 (Boneyard Creek at Race Street, Urbana, III.) for storm events analyzed during this study. 


\section{Tables}

1. Selected stormwater improvements in the Boneyard Creek watershed in Champaign-Urbana, III.

2. Storm-event periods simulated by using the RUNOFF module of the Stormwater Management Model (SWMM) on Boneyard Creek in Champaign-Urbana, III., for this study

3. Precipitation depths and resulting stages of flow at USGS streamgage 03337100

(Boneyard Creek at Lincoln Avenue, Urbana, III.) for storm events analyzed during this study.....

4. Observed peak discharges at USGS streamgage 03337100 (Boneyard Creek at Lincoln Avenue, Urbana, III.) for storm events analyzed during this study

5. Observed peak discharges and stages at selected streamgages on Boneyard Creek, Urbana, III., for storm events analyzed during this study.

6. Results of discharge measurement uncertainty analysis on selected measurements at USGS streamgage 03337100 (Boneyard Creek at Lincoln Avenue, Urbana, III.).....

7. Instantaneous-discharge-computation uncertainty components for a discharge of 700 cubic feet per second for USGS streamgage 03337100 (Boneyard Creek at Lincoln Avenue, Urbana, III.) ..

8. Observed peak discharges and their 95-percent confidence intervals, assuming a measurement error of 5 percent, at USGS streamgage 03337100 (Boneyard Creek at Lincoln Avenue, Urbana, III.) for storm events analyzed during this study...

9. Comparison of simulated and observed peak discharges at USGS streamgage 03337100 (Boneyard Creek at Lincoln Avenue, Urbana, III.) for storm events analyzed during this study...

10. Simulated peak discharges and differences between simulated and observed peak discharges at USGS streamgage 03337100 (Boneyard Creek at Lincoln Avenue, Urbana, III.) for storm events analyzed during this study

11. Comparison of simulated and observed peak stages at USGS streamgage 03337100 (Boneyard Creek at Lincoln Avenue, Urbana, III.) for storm events analyzed during this study.....

12. Comparison of simulated and observed peak discharges at USGS streamgage 03337000 (Boneyard Creek at Urbana, III.) on the campus of the University of Illinois at Urbana-Champaign for storm events analyzed during this study......

13. Comparison of simulated and observed peak stages at USGS streamgage 03337000 (Boneyard Creek at Urbana, III.) on the campus of the University of Illinois at Urbana-Champaign for storm events analyzed during this study.

14. Comparison of simulated and observed peak stages at USGS streamgage 03337250 (Boneyard Creek at Race Street, Urbana, III.) for storm events analyzed during this study. 


\section{Conversion Factors and Vertical Datum}

\begin{tabular}{lcl}
\hline \multicolumn{1}{c}{ Multiply } & By & \multicolumn{1}{c}{ To obtain } \\
\hline inch (in.) & Length & \\
foot (ft) & 25.4 & millimeter $(\mathrm{mm})$ \\
mile (mi) & 0.3048 & meter $(\mathrm{m})$ \\
\hline & 1.609 & kilometer $(\mathrm{km})$ \\
\hline acre & Area & \\
acre & 0.4047 & hectare $(\mathrm{ha})$ \\
square mile $\left(\mathrm{mi}^{2}\right)$ & 0.004047 & square kilometer $\left(\mathrm{km}^{2}\right)$ \\
square mile $\left(\mathrm{mi}^{2}\right)$ & 259.0 & hectare (ha) \\
\hline & 2.590 & square kilometer $\left(\mathrm{km}^{2}\right)$ \\
\hline acre-foot (acre-ft) & Volume & \\
\hline & 1,233 & cubic meter $\left(\mathrm{m}^{3}\right)$ \\
\hline cubic foot per second $\left(\mathrm{ft}^{3} / \mathrm{s}\right)$ & Flow rate & \\
mile per hour (mi/h) & 0.02832 & cubic meter per second $\left(\mathrm{m}^{3} / \mathrm{s}\right)$ \\
\hline
\end{tabular}

Vertical coordinate information is referenced to the National Geodetic Vertical Datum of 1929 (NGVD 29). 


\title{
Using Observed Postconstruction Peak Discharges to Evaluate a Hydrologic and Hydraulic Design Model, Boneyard Creek, Champaign and Urbana, Illinois
}

\author{
By Thomas M. Over, David T. Soong, and Robert R. Holmes, Jr.
}

\section{Abstract}

Boneyard Creek — which drains an urbanized watershed in the cities of Champaign and Urbana, Illinois, including part of the University of Illinois at Urbana-Champaign (UIUC) campus - has historically been prone to flooding. Using the Stormwater Management Model (SWMM), a hydrologic and hydraulic model of Boneyard Creek was developed for the design of the projects making up the first phase of a long-term plan for flood control on Boneyard Creek, and the construction of the projects was completed in May 2003. The U.S. Geological Survey, in cooperation with the Cities of Champaign and Urbana and UIUC, installed and operated stream and rain gages in order to obtain data for evaluation of the designmodel simulations. In this study, design-model simulations were evaluated by using observed postconstruction precipitation and peak-discharge data.

Between May 2003 and September 2008, five high-flow events on Boneyard Creek satisfied the study criterion. The five events were simulated with the design model by using observed precipitation. The simulations were run with two different values of the parameter controlling the soil moisture at the beginning of the storms and two different ways of spatially distributing the precipitation, making a total of four simulation scenarios. The simulated and observed peak discharges and stages were compared at gaged locations along the Creek. The discharge at one of these locations was deemed to be critical for evaluating the design model. The uncertainty of the measured peak discharge was also estimated at the critical location with a method based on linear regression of the stage and discharge relation, an estimate of the uncertainty of the acoustic Doppler velocity meter measurements, and the uncertainty of the stage measurements.

For four of the five events, the simulated peak discharges lie within the 95-percent confidence interval of the observed peak discharges at the critical location; the fifth is just outside the upper end of this interval. For two of the four simulation scenarios, the simulation results for one event at the critical location were numerically unstable in the vicinity of the discharge peak. For the remaining scenarios, the simulated peak discharges over the five events at the critical location differ from the observed peak discharges (simulated minus observed) by an average of 7.7 and -1.5 percent, respectively. The simulated peak discharges over the four events for which all scenarios have numerically stable results at the critical location differs from the observed peak discharges (simulated minus observed) by an average of $-6.8,4.0,-5.4$, and 1.5 percent, for the four scenarios, respectively. Overall, the discharge peaks simulated for this study at the critical location are approximately balanced between overprediction and underprediction and do not indicate significant model bias or inaccuracy. Additional comparisons were made by using peak stages at the critical location and two additional sites and using peak discharges at one additional site. These comparisons showed the same pattern of differences between observed and simulated values across events but varying biases depending on streamgage and measurement type (discharge or stage). Altogether, the results from this study show no clear evidence that the design model is significantly inaccurate or biased and, therefore, no clear evidence that the modeled flood-control projects in Champaign and on the University of Illinois campus have increased flood stages or discharges downstream in Urbana.

\section{Introduction}

Boneyard Creek (fig. 1) drains an urbanized watershed of approximately $7.45 \mathrm{mi}^{2}$ that flows, in upstream-to-downstream order, through the city of Champaign, Ill., the campus of the University of Illinois at Urbana-Champaign (UIUC), and the city of Urbana, Ill. Recurrent and increasing flooding problems along Boneyard Creek resulted from the land-cover change and storm sewerage associated with the urbanization (Wilson, 1978; Berns, Clancy and Associates, 1998; Chaille and Yen, 2000). To remedy these problems, several flood-control projects were constructed over the past several decades (table 1). These projects began in the late 1950s and early 1960s with the construction of the Northwest Diversion Structure, which diverts the upper $1.12 \mathrm{mi}^{2}$ of drainage directly to the Saline 


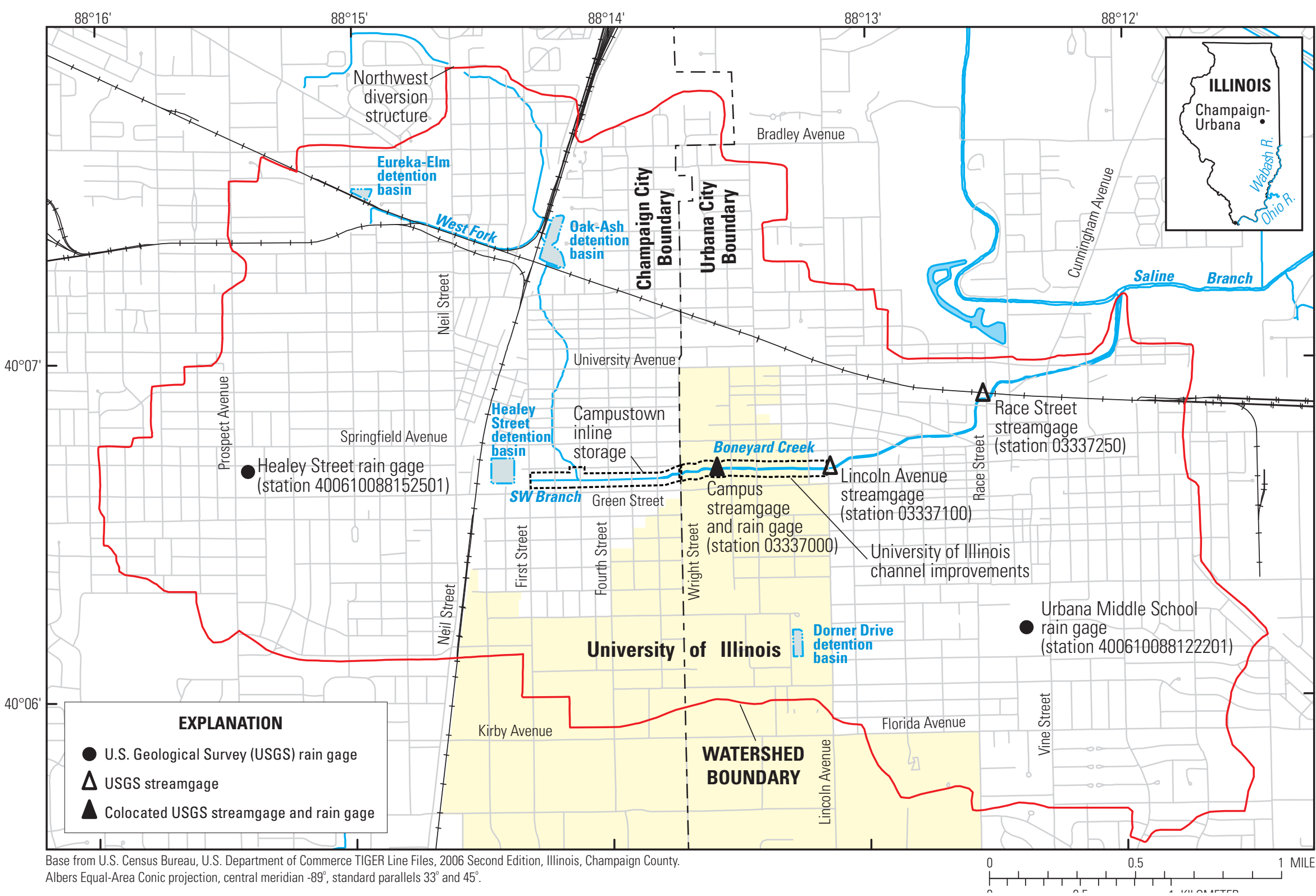

Figure 1. Boneyard Creek watershed in Champaign-Urbana, III., and locations of flood-control improvements, U.S. Geological Survey (USGS) rain gages and streamgages. 
Branch (fig. 1), and the deepening and widening of the channel in Urbana. In 1980s and 1990s, two detention basins were built in Champaign (Oak-Ash and Eureka-Elm) and one on the UIUC campus (Dorner Drive).

In the 1990s, an additional set of flood-control projects comprising Phase I of five planned phases of further Boneyard Creek improvement projects by the City of Champaign were designed. As part of the design process, simulations of the Stormwater Management Model (SWMM) were used to test the behavior of the system with the designed changes in place. These projects, consisting of channel improvements and detention facilities (including work by UIUC) and constructed between 1998 and May 2003, were designed to address flooding problems in Champaign and on the UIUC campus while not increasing flooding downstream in Urbana (Berns, Clancy and Associates, 1998). Nevertheless, when originally proposed, the projects met with public controversy, and the City of Urbana commissioned reviews of the design and the associated modeling (Rust Environment \& Infrastructure, 1997, 1998).

As an extension of this review of the projects, the U.S. Geological Survey, in cooperation with the Cities of Champaign and Urbana and with UIUC, installed and operated rain gages and streamgages to evaluate the design model after construction. The study began in 2000 with the installation of supplementary rain, stage, and streamgages. In 2008, after five peak discharges at the Lincoln Avenue streamgage were determined to exceed the qualifying magnitude of $696 \mathrm{ft}^{3} / \mathrm{s}$ (the estimated 0.20 -probability annual maximum flood; Jeff Smith, City of Champaign, written commun., 1999), the evaluation of design model simulations began. This part of the study included the use of existing precipitation and streamgage data in addition to data from the supplementary study gages. The uncertainties inherent in the observation of precipitation and streamflow data and the effect of the antecedent moisture condition of the watershed and its uncertainty were considered in the study design.

\section{Technical Approach}

In order to evaluate the accuracy of the design model predictions of the effects of the Phase I flood-control projects, postconstruction observed events were simulated for this study by using the design model, as modified to represent the asbuilt conditions. Other approaches for evaluating the impact of the flood-control projects were considered but were determined to be infeasible. An empirical approach for evaluating the effects of the flood-control projects would require data that would have to have been obtained before construction. For example, if similar storms before and after the Phase I projects were to be compared, adequate precipitation data during both pre- and post-project periods would be needed to characterize the rainfall events as well as streamflow at the location(s) of interest. The similar-storms approach would also require subjective judgments of "similarity" between events because of the complex structure of precipitation and antecedent soil moisture in space and time. A flood-frequency approach would require only streamflow data, but those data would need to be available at the relevant location(s) and for a sufficient period with stationary watershed conditions in both the pre- and postproject periods to make the analysis valid.

On Boneyard Creek, streamflow data have been collected by the USGS since 1948 at a streamgage downstream from Wright Street on the UIUC campus (station 03337000 , labeled as the Campus streamgage in fig. 1), but precipitation data during this period are spatially and temporally insufficient because only one recording rain gage was available, and it is

Table 1. Selected stormwater improvements in the Boneyard Creek watershed in Champaign-Urbana, III.

$\left[\mathrm{mi}^{2}\right.$, square miles; acre-ft, acre-feet; ft, feet $]$

Year Description

1960 Northwest Diversion Structure completed. Diverts upper $1.12 \mathrm{mi}^{2}$ of the watershed directly into the Saline Branch.

1963-64 Boneyard Creek main channel is deepened in Urbana by 4-5 feet from Lincoln Avenue downstream to Race Street, leaving a drop a Lincoln Avenue. Channel cross section is changed to a rectangular section with sheet-piling walls and concrete bottom.

1980-97 Three stormwater detention facilities constructed in the Boneyard Creek watershed: Oak-Ash (59 acre-ft), Eureka-Elm (14.6 acre-ft), and Dorner Drive (12 acre-ft).

1998-May 2003 Phase I of Champaign's Boneyard Improvement Plan is constructed. Champaign constructs 114 acre-ft detention basin at Healey Street and buries and enlarges approximately 2,700 ft of the Boneyard Creek through Campustown (ending at Wright Street), providing an additional 20 acre-ft of detention storage and estimated 25- to 100-year flood protection. A flow restrictor is installed at Wright Street to offset the additional flow capacity provided by the Campustown improvements not offset by Healey detention. UIUC lowers and widens 2,600 ft of the channel through its campus (Wright Street to Lincoln Avenue), eliminating the drop at Lincoln Avenue.

September 2008 Construction begins on Phase II of Champaign's long-range Boneyard Improvement Plan. 
southwest of the watershed boundary. Because the storms that typically induce the highest peak flows for Boneyard Creek are summer convective thunderstorms, one rain gage outside the basin is inadequate to represent the spatially heterogeneous rainfall that accompanies convective thunderstorms in the Midwestern United States. Furthermore, the ideal location for the streamgage on which to base an evaluation would be at Lincoln Avenue in Urbana, about 2,000 ft downstream from the Campus streamgage, because that location is at the downstream end of the part of the watershed where the Phase I flood-control projects were constructed. In addition, as is evident from table 1, the Boneyard Creek watershed has had numerous hydrologic alterations throughout its history, so it fails to have the stationary watershed conditions that are needed for a valid comparison by the flood-frequency approach.

Because adequate preproject hydrologic data do not exist in the study area to implement an empirical approach to project evaluation by preproject and postproject comparison, it was necessary to use an alternative approach. The approach described herein is based on evaluating the model used to design the projects. The design and permitting of the Boneyard flood-control projects were predicated on the assumption of the accuracy of Stormwater Management Model (SWMM) results used in the design process to estimate peak discharges for a given set of (design storm) rainfall inputs. This assumption can be validated if the accuracy of SWMM model can be demonstrated in simulating storm events in the real-world conditions represented in the model; that is, the conditions of the post-project period. This approach requires precipitation and streamflow data to be collected during only the post-project period, and it requires these data only for several events of appropriate magnitude, rather than for a long series of stationary conditions as in the flood-frequency approach; furthermore, it does not rely on evaluations of storms subjectively defined as "similar."

The magnitude of qualifying events for the study $\left(696 \mathrm{ft}^{3} / \mathrm{s}\right)$, the estimated 0.20 probability annual maximum flood at station 03337000 , was selected at a relatively low value because this implies that it was likely to be exceeded at least a few times in a reasonable period of time (the observation period for the study was set to end after three qualifying events or 10 years, whichever came first) and because higher, out-of-bank flows would make the discharge measurements much more challenging. The selected magnitude turned out to have been well chosen, because the first qualifying event occurred in July 2003, just two months after the Phase I projects were completed, followed by a second in June 2007 and then three in 2008, with the last occurring just as construction of the next phase of flood-control projects was about to begin, which would significantly change the conditions in the Creek and invalidate further comparisons. The relatively high probability of the floods that are analyzed in this study however also leaves some uncertainty regarding how the model and observations would compare for higher, less probable flood events.

\section{Purpose and Scope}

The results of the Boneyard Creek design simulation model evaluation study by the USGS, in cooperation with the Cities of Champaign and Urbana and the UIUC, are reported herein. An estimated uncertainty of the peak discharges at the critical location was determined and is presented as a 95-percent confidence interval, along with the design model simulation results. The uncertainty introduced by rain gages sampling a spatially variable rainfall field is addressed approximately through comparing separate simulations with spatially uniform and spatially variable precipitation inputs to the model. Atgage uncertainty in precipitation measurement is not explicitly addressed; instead, a multiple-event sample is simulated to control for the errors in representing highly variable rainfall field with a necessarily limited number of rain gages. The antecedent moisture condition of the watershed was estimated by beginning the simulation during the event prior to the event of interest; simulations using two values of the parameter controlling the recovery of soil infiltration capacity during the dry period between the events were done to assess the sensitivity of the model results to the uncertainty of the moisture condition. The design simulation model is considered to be accurate or conservative if the simulated peaks of the observed flow events are within or greater than the 95-percent confidence intervals of the observed peak discharges. Results of comparisons between simulated and observed stages at the critical location and between simulated and observed discharge and stage at additional streamgages along the Creek also are presented. 


\section{Methodology}

The basic methodology of this study consists of modeling the response of flows in Boneyard Creek to observed precipitation events by means of the model used to design the 1998-2003 Boneyard Creek improvements and comparing the modeled and observed peak discharges and stages at the USGS streamgage on Boneyard Creek at Lincoln Avenue in Urbana (taking into account the uncertainty in the computation of the observed discharge) and at supplementary streamgages on the UIUC campus and at Race Street in Urbana. This section describes the use of the design model in this study, the precipitation and streamflow data and their processing, and the method used to estimate the uncertainty in the observed peak discharges.

\section{Modeling With the Stormwater Management Model (SWMM)}

As described in Berns, Clancy and Associates (1998), the model development for the design of the Phase I Boneyard Creek flood-control improvements was completed by Camp Dresser \& McKee, Inc. (CDM), by using the SWMM4 model with design-storm precipitation with annual exceedance probabilities down to 1 percent (the 100-year flood) based on the methods and data given in Illinois State Water Survey Bulletin 70, Circular 172, and Circular 173 (Huff and Angel, 1989a,b; Huff, 1990). The version of SWMM4 used was an in-house CDM version called CDMSWMM that did not include the final design of the UIUC channel (Pat Lach, CDM, written commun., May 7, 2004). After the final design and construction of the UIUC channel, CDM staff updated the geometry of the model to include the as-built properties of the channel, updated the input file to make it compatible with SWMM4.4H (which was by then the official public version of SWMM and which included many of the features added by CDM to CDMSWMM), and provided the model to the USGS. This as-built SWMM4.4H model was taken as the design model to be evaluated in this study. In 2005, EPA released a complete rewrite of SWMM as SWMM5, but the cooperators and the USGS agreed that there was a strong likelihood that a SWMM5 version of the model would be substantially different from the SWMM4 design model and therefore would be inconsistent with the objective of the study.

The SWMM4 model system contains seven individual modules (James and others, 2003); this study makes use of the modules for precipitation analysis (RAIN module), runoff generation (RUNOFF module), and extended transport analysis (EXTRAN module). The RAIN module formats rainfall data for use as input to the RUNOFF module. The RUNOFF module simulates the generation and hydrologic routing of runoff, including all the basic hydrologic processes: precipitation, snow accumulation and melting, evaporation, infiltration, groundwater/surface-water interaction, and hydrologic routing of runoff overland and through pipes. The model system also includes a water-quality component to simulate the transport of constituents of interest in the runoff. Because flood events on Boneyard Creek generally result from summer thunderstorms and base flow in the creek is small and therefore does not contribute significantly to flood flows, groundwater and snow are not simulated in the Boneyard SWMM model. Water quality is likewise not addressed in this model.

Infiltration in the SWMM RUNOFF module as implemented for the Boneyard model is simulated by the Horton infiltration equation. The associated parameters depend on land use, soil type, and the antecedent moisture condition of the soil; determination of the associated parameters is described in Berns, Clancy and Associates (1998). All RUNOFF parameter values were maintained as found in the final SWMM4.4H model except the following, which were changed to enable use of the model for simulating observed events rather than in a design-storm mode: (1) evaporation parameters were modified to reflect the month in which each observed event occurred, and (2) the parameter REGEN [dimensionless], defined as the ratio of the exponential decay rate $\left[\mathrm{T}^{-1}\right]$ at which soil infiltration capacity is regenerated to the exponential decay rate $\left[\mathrm{T}^{-1}\right]$ at which soil infiltration capacity decays during infiltration, was modified. The REGEN parameter is irrelevant for simulating design storms and had been given the default value of 0.01 ; this value appeared to perhaps allow for the infiltration capacity to regenerate too quickly given the soil characteristics in the Boneyard watershed (following the guidance in James and others, 2003). Therefore results from using REGEN values of 0.01 and 0.001 are presented in this report.

The other change in the use of the RUNOFF module between the design-storm mode and the observed-event mode used in this study is in the setting of the antecedent moisture condition for the soil, which affects the initial value of the infiltration capacity in the Horton infiltration equation. In the design model, this condition was taken as type II or "average." For observed events simulated here, the intent is to match conditions as they actually were at the beginning of the storm. Rather than changing the Horton parameters as determined by CDM for the design model, in this study the antecedent moisture condition was simulated by means of a continuous simulation approach: the RUNOFF modeling was initialized at average conditions at the beginning of the rain event prior to each peak event of interest (usually a few days earlier; see table 2). During this prior event and the intervening dry period, the infiltration capacity decayed and then was regenerated (at a rate depending on the value of REGEN as discussed above) so that in this way it was adjusted to the approximate conditions that actually led up to the peak event of interest.

Using the discharges simulated by the RUNOFF module as input, the EXTRAN module simulates the one-dimensional gradually varied unsteady flow of water based on the conservation of mass and momentum through a network of links (pipes and open channels) connected by nodes (usually manholes) and other system components including weirs, pumps, orifices, storage basins, and outfall structures. The basic differential equations are then solved in finite-difference 
Table 2. Storm-event periods simulated by using the RUNOFF module of the Stormwater Management Model (SWMM) on Boneyard Creek in Champaign-Urbana, III., for this study.

\begin{tabular}{ccc}
\hline $\begin{array}{c}\text { Date of peak discharge } \\
\text { (month/day/year) }\end{array}$ & $\begin{array}{c}\text { Begin date of storm-event simulation } \\
\text { (month/day/year) }\end{array}$ & $\begin{array}{c}\text { End date of storm-event simulation } \\
\text { (month/day/year) }\end{array}$ \\
\hline $07 / 09 / 2003$ & $07 / 08 / 2003^{\mathrm{a}}$ & $07 / 11 / 2003$ \\
$06 / 26 / 2007$ & $06 / 21 / 2007$ & $06 / 28 / 2007$ \\
$06 / 03 / 2008$ & $05 / 30 / 2008$ & $06 / 05 / 2008$ \\
$07 / 08 / 2008$ & $07 / 02 / 2008$ & $07 / 09 / 2008$ \\
$09 / 14 / 2008$ & $09 / 11 / 2008$ & $09 / 16 / 2008$ \\
\hline
\end{tabular}

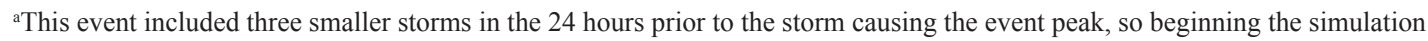
period just the day before the peak event was deemed sufficient to set the antecedent moisture condition for the peak event.

form. Three numerical solution schemes are available in SWMM4: these are called "explicit" (parameter ISOL $=0$ ), "enhanced explicit" (ISOL $=1)$, and "iterative" $(\mathrm{ISOL}=2)$. The EXTRAN model provided by CDM used the explicit method with a timestep (parameter DELT) of 0.1 second. The EXTRAN runs required considerable computer time (on the order of an hour on a desktop PC running Windows XP) and encountered occasional problems with numerical stability in the simulation of the selected observed events; therefore, other values of ISOL and DELT were tested. However, the values of ISOL and DELT from the original model were found to have the best stability and were used for all the results shown in this report. All other EXTRAN geometric and numerical parameters were maintained as in the final SWMM4.4H model provided by CDM.

\section{Sources and Processing of Data}

\section{Precipitation Data}

Precipitation data available to this study include continuous records at 5-minute intervals at three tipping-bucket rain gages operated by the USGS as part of this study and a variable number of daily nonrecording rain gages operated by volunteers in the Boneyard Precipitation Network (BYN) (http://www.isws.illinois.edu/atmos/boneyard/). The USGSoperated rain gages used are those at Healey Street (USGS station 400641088152501), at the Campus streamgage (USGS station 03337000), and at Urbana Middle School (USGS station 400610088122201). Their data were obtained from the internal USGS ADAPS database. Until the incorporation of the BYN into the Community Cooperative Rain, Hail, and Snow (CoCoRAHS) network in November 2008, the BYN used wedge-shaped gages that were usually read at 7:00 a.m. local standard time (Westcott and others, 2008). Despite the differences in the recording intervals, the two sources complement each other to provide better spatial coverage of precipitation for the Boneyard Creek watershed.
Because the runoff events being evaluated in this study are caused by short-duration, high-intensity summer convective rainfall events - which generally last, at most, a few hours - and the highest flows correspond to the heaviest rainfall intensity-which usually occurred within a period of 12 hours - the precipitation inputs used in the simulations were at a 5-minute interval corresponding to the measurements at the USGS rain gages. Disaggregating the daily data from the BYN stations to the 5-minute time interval was accomplished by following the temporal distribution of the nearest USGS rain gage but preserving the daily total depth of each gage. Assigning precipitation time series to subbasins to represent spatial distribution of a rainstorm was achieved by using the Thiessen (1911) polygon approach (fig. 2). The USGS rain gage at Urbana Middle School was generally found to record anomalously low depths, so it was not used for distributing precipitation spatially; however, its time pattern was used for disaggregation.

The spatial distribution of precipitation obtained by applying the Thiessen polygon method was used in both spatially uniform and spatially variable modes. In the spatially uniform mode, the fraction of the basin lying inside each polygon was used as a weight to obtain a spatial average value for each time step that was applied uniformly to the entire simulated watershed. In the spatially variable mode, at each time step, each subbasin was assigned the precipitation depth in the polygon in which it lies so that the precipitation was spatially variable. The spatially uniform mode corresponds to the spatial structure of the design storms used for simulating the system during the design phase, whereas the spatially variable mode should provide a more realistic representation of the actual storm event.

The scope of this study does not include a direct assessment of precipitation-measurement uncertainty or its effects; however, one particular phenomenon that can lead to a significant negative bias during thunderstorms or other windy periods - wind-induced gage catch deficiency — was examined. Wind data from the Automated Surface Observing System (ASOS) at Willard Airport in Champaign were obtained 


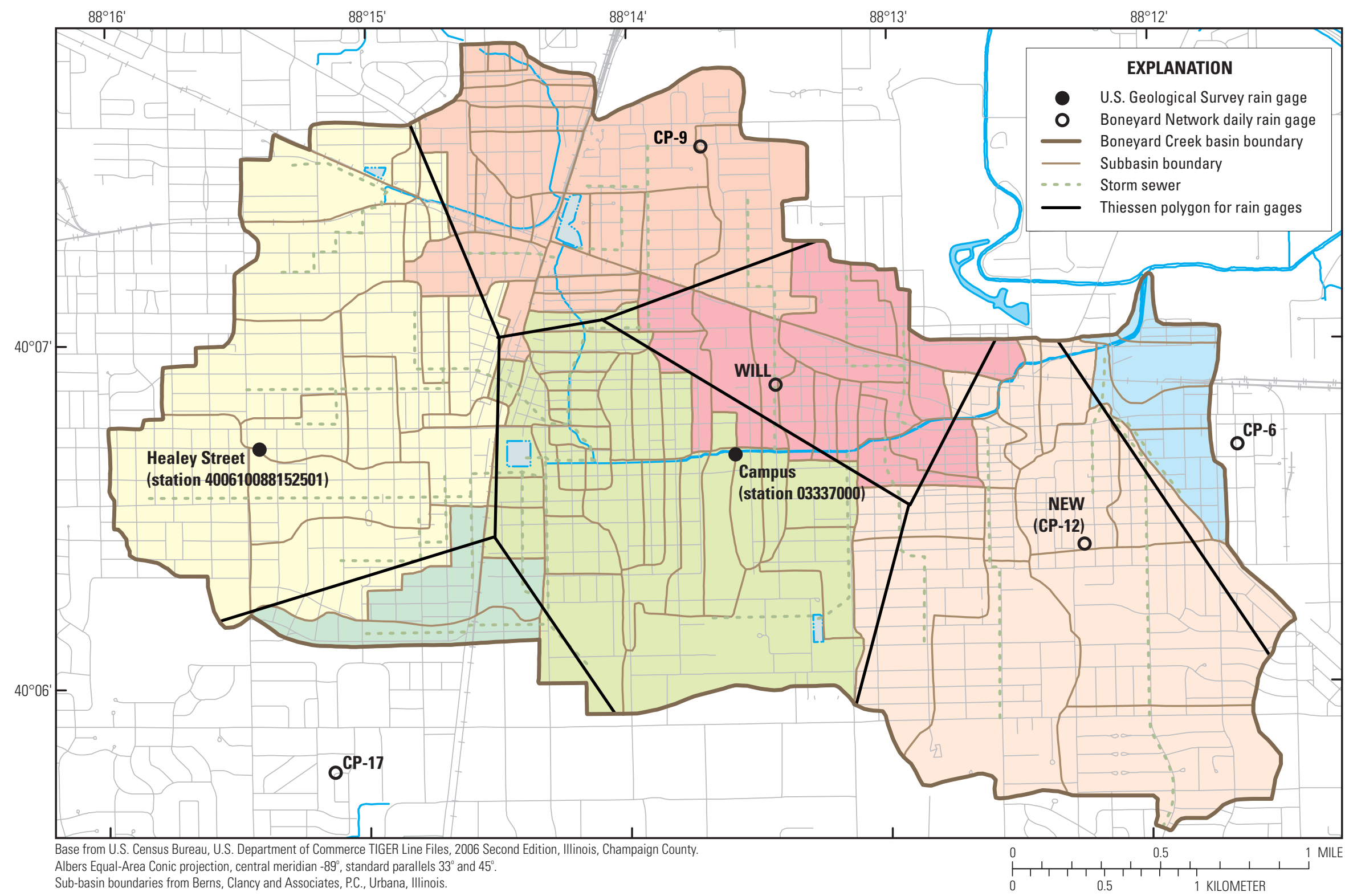

Figure 2. Example of Thiessen polygons covering subbasins in the Boneyard Creek Stormwater Management Model (SWMM). The group of subbasins assigned to each polygon is shown by using a distinct color. 
from Weather Underground (http://www.wunderground.com/) during the qualifying storm events to characterize the possible gage catch deficiency. These data show that all five of the events were associated with elevated wind speeds, with typical wind speeds of $10-20 \mathrm{mi} / \mathrm{h}$ and gusts to at least $30 \mathrm{mi} / \mathrm{h}$. For reference, the approximate expected undercatch for an unshielded gage is about 10 percent at $10 \mathrm{mi} / \mathrm{h}$ and 20 percent at $20 \mathrm{mi} / \mathrm{h}$ (Larson and Peck, 1974). However, because no gage catch deficiency correction was made to the design storms in Bulletin 70 (Huff and Angel, 1989a; Jim Angel, Illinois State Water Survey, written commun., 2010) and because the wind measurement at Willard Airport is in an open field at a 10-m height whereas the rain gages used in this study are usually in more sheltered conditions at a much lower height, it was concluded that (a) it is unclear if correction of the precipitation data for wind-induced gage catch deficiency is appropriate and (b) choosing the appropriate magnitude of such a correction would be difficult. Therefore, no such correction was made.

\section{Stream-Discharge and Stage Data}

In accordance with the study design, the discharge data from the streamgage on Boneyard Creek at Lincoln Avenue (USGS station 03337100) were the primary data used to evaluate the performance of design model. Some further details regarding this streamgage are warranted because of the importance of the peaks recorded there for this study. The streamgage began operation on December 11, 2001. The relevant equipment installed consisted of a continuous pressure sensor (for computing stage), a two-path acoustic velocity meter (AVM), and a crest-stage gage. On May 5, 2003, the temporary cofferdam upstream from the gage was removed at the end of the Boneyard Creek Phase I improvements project. On September 23, 2004, an uplooking acoustic Doppler velocity meter (ADVM) was installed on the bottom of the channel along with a 6- by 6-in. angle iron to provide low-flow control. The AVM proved to be unreliable partly because its measurement paths were submerged only intermittently, and it was removed on November 9, 2005.

Acoustic technology designed to measure velocity was installed at this site because of the intermittent backwater affecting the stage-discharge relation caused by the 54 -in. storm sewer that drains into Boneyard Creek under the Lincoln Avenue bridge just downstream from the gage. The ADVM did not successfully record the peak flows of interest, so discharge computations at the gage throughout its period of operation have been by means of stage-discharge ratings (SDRs), which are constructed by fitting a smooth curve to field-measured discharges and their corresponding stages (gage heights) (fig. 3). SDR 1 was based on the 24 measurements made in the first water year ${ }^{1}$ of operation (ending September 30, 2002), with discharges ranging from 2.05 to

\footnotetext{
"Water year" in USGS reports dealing with surface-water supply is the 12-month period October 1 through September 30. The water year is designated by the calendar year in which it ends and which includes 9 of the 12 months. Thus, the year ending September 30, 2008, is called "water year 2008."
}

$271 \mathrm{ft}^{3} / \mathrm{s}$ (fig. 3). Discharges continued to be computed by using SDR 1 until December 28, 2005, when the lower part of the rating was revised, creating SDR 2 (fig. 3), as a result of new measurements showing the effect of the angle iron installed in 2004. SDR 2 was used to compute discharges until October 17, 2007, when SDR 3, which adjusted the high end of the rating, went into effect (fig. 3). SDR 3 was used throughout water year 2008. After three high peak flows in summer 2008, SDR 4 was established and went into effect on May 13, 2009; SDR 4 is nearly identical to SDR 3 except for being extended to higher flows and stages (fig. 3).

Supplemental data from two additional streamgages on Boneyard Creek were also collected for use in this study: Boneyard Creek at Urbana (the Campus streamgage, USGS station 03337000) and Boneyard Creek at Race Street (USGS station 03337250). The Campus streamgage is about 2,000 ft upstream from Lincoln Avenue at a pedestrian bridge on the campus of the UIUC (fig. 1) and is a source of both stage and discharge data, the latter computed from a stage-discharge rating in the same general manner as for the gage at Lincoln Avenue. As mentioned, this gage has been in operation since 1948 except for brief outages for maintenance or moving and reinstallation. The gage was in its present location for the duration of this study. The Race Street streamgage is a stageonly gage about 3,500 ft downstream from the Lincoln Avenue streamgage (fig. 1).

\section{Events Selected for Analysis}

Between May 2003, when the Phase I flood-control improvements were completed, and September 2008, when construction of the Phase II improvements began, five events officially exceeded the $696-\mathrm{ft}^{3} / \mathrm{s}$ threshold at Lincoln Avenue. Information regarding these events is given in table 3 , including the date and time, the gage height and corresponding elevation, and the estimated depth of precipitation that occurred over the watershed during three periods prior to the peak discharge. The peak discharges themselves are listed in table 4 . The first precipitation period presented in table 3 was selected as the 2 hours before the peak because all the high flow events were preceded by significant precipitation events of 1-2 hours' duration. The additional two precipitation periods of 24 hours' duration were selected to give an indication of antecedent soil-moisture conditions before the precipitation event causing the high flow.

Table 4 lists the official observed peak discharges (where an official peak is defined as the published annual maximum peak discharge or the value that would have been published as the annual maximum peak if it had been the largest) and some alternative values for observed peak discharge that are obtained depending on two factors: (1) the SDR used and (2) the application of shifts. Because the streamgage on Boneyard Creek at Lincoln Avenue is relatively new, ratings have 
been recomputed regularly as additional discharge measurements have been made. Because SDR 4 is the newest rating and no channel modifications affecting the high flow stagedischarge relation have been made over the period considered in this study, adjusting the peak discharges to the values they would have by using SDR 4 constitutes the best available information. Therefore, SDR 4 peak discharges are used as the basis for comparison in this report. It can be seen from table 4 that switching from SDRs 1 and 2 to SDR 4 has an appreciable effect on the first two events; however, for the last three events (which occurred in 2008 and whose discharges were computed by using SDR 3), the effect of switching to SDR 4 is quite small. The issue of shifts is addressed next.

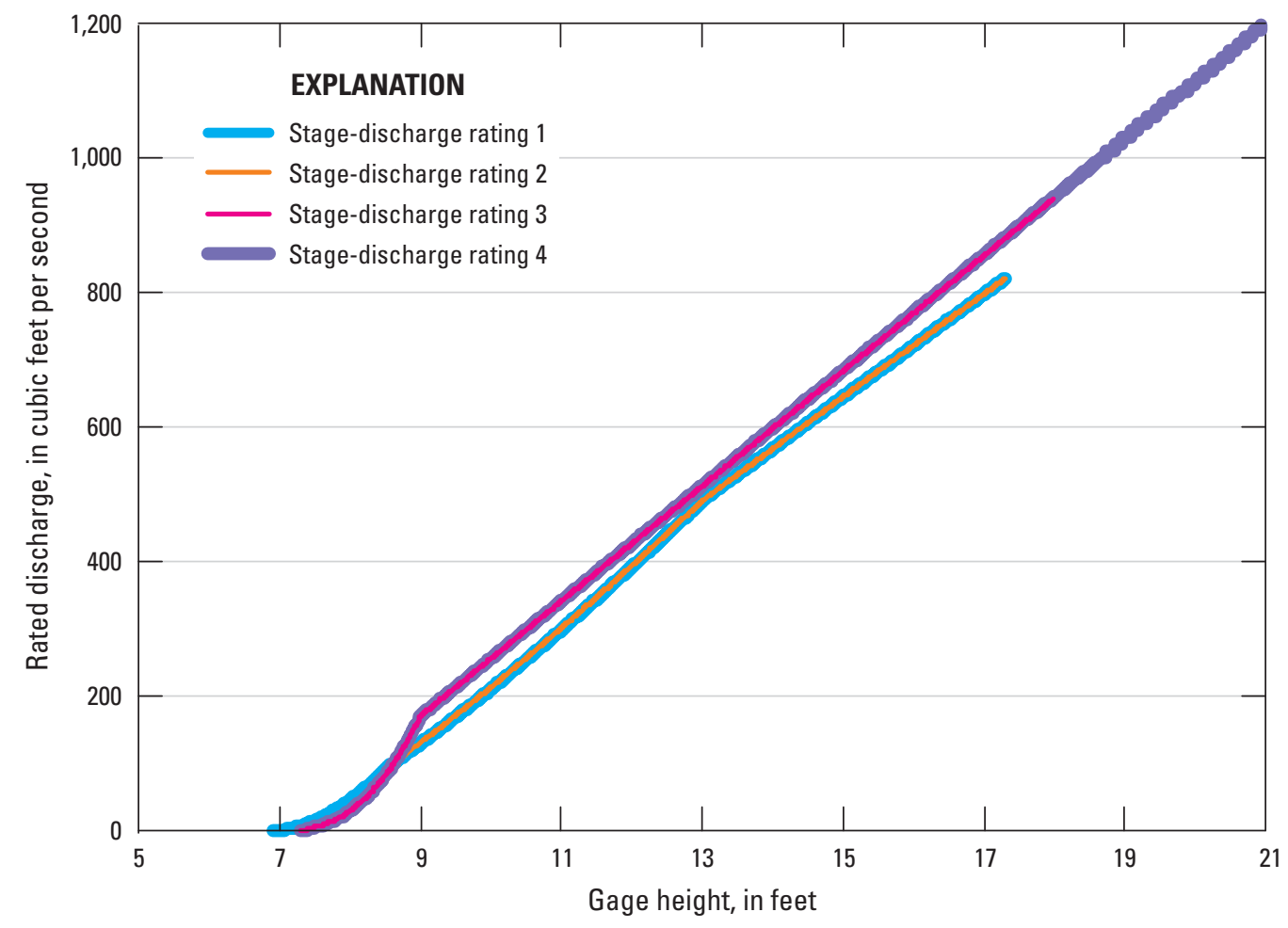

Figure 3. Stage-discharge ratings used for USGS streamgage 03337100 (Boneyard Creek at Lincoln Avenue, Urbana, III.), water years 2002 through 2009.

Table 3. Precipitation depths and resulting stages of flow at USGS streamgage 03337100 (Boneyard Creek at Lincoln Avenue, Urbana, III.) for storm events analyzed during this study.

[in., inches; ft, feet; NGVD 29, National Geodetic Vertical Datum of 1929]

\begin{tabular}{|c|c|c|c|c|c|c|}
\hline \multicolumn{2}{|c|}{$\begin{array}{l}\text { Occurrence of observed } \\
\text { peak discharge }\end{array}$} & \multicolumn{2}{|c|}{$\begin{array}{l}\text { Stage of observed } \\
\text { peak discharge }\end{array}$} & \multicolumn{3}{|c|}{$\begin{array}{l}\text { Depth of storm precipitation a } \\
\text { (in.) }\end{array}$} \\
\hline $\begin{array}{c}\text { Date } \\
\text { (month/day/year) }\end{array}$ & $\begin{array}{c}\text { Time } \\
\text { (hour/minutes) }\end{array}$ & $\begin{array}{l}\text { Gage height } \\
\text { (ft) }\end{array}$ & $\begin{array}{c}\text { Elevation } \\
\text { (ft, NGVD 29) }\end{array}$ & $\begin{array}{l}2 \text { hours prior to } \\
\text { peak discharge }\end{array}$ & $\begin{array}{l}\text { 2-26 hours prior to } \\
\text { peak discharge }\end{array}$ & $\begin{array}{l}26-50 \text { hours prior } \\
\text { to peak discharge }\end{array}$ \\
\hline 07/09/2003 & $17: 55$ & 17.00 & 711.00 & 2.54 & 2.83 & 0.00 \\
\hline $06 / 26 / 2007$ & 10:34 & 14.63 & 708.63 & 1.35 & 0.02 & 0.00 \\
\hline $06 / 03 / 2008$ & 05:14 & 16.80 & 710.80 & 1.45 & 0.39 & 0.00 \\
\hline 07/08/2008 & $17: 54$ & 16.29 & 710.29 & 2.13 & 0.00 & 1.39 \\
\hline 09/14/2008 & 09:56 & 17.26 & 711.26 & 2.15 & 1.20 & 0.22 \\
\hline
\end{tabular}

aPrecipitation depths appearing in this table are watershed-average values obtained by using the Thiessen polygon method. 
Only one of the qualifying events, on June 26, 2007, required application of a shift in the computation of its official peak discharge (table 4). Shifts are adjustments to ratings to account for temporary changes in the elevation of the hydraulic control at a streamgage, such as would be caused by the accumulation of debris on the control during a flood. For the Boneyard Creek at Lincoln Avenue streamgage, shifts have been applied usually to account for the effects of the 54-in. storm drain that discharges into the creek just downstream from the gage. Because the flow from this storm drain is unmeasured, its effects are observed only when a discharge measurement is made. For this event, the peak stage occurred at 10:34 a.m., and a measurement was made between 10:47 and 10:55 a.m. To make the measurement (discharge of $653 \mathrm{ft}^{3} / \mathrm{s}$ at a gage height of $13.83 \mathrm{ft}$ ) lie on the rating curve that was then in use (SDR 2), the stage had to be increased (shifted) by $1.28 \mathrm{ft}$ (fig. 4). The same shift was applied for the official discharge computation because the peak stage had occurred so recently, raising the computed discharge from the SDR 2 value at a gage height of 14.63 of $616 \mathrm{ft}^{3} / \mathrm{s}$ to the official value of $714 \mathrm{ft}^{3} / \mathrm{s}$. If no shift had been applied, the value at the time of the peak stage $\left(616 \mathrm{ft}^{3} / \mathrm{s}\right)$ would have been less than the measured value when the stage was only $13.83 \mathrm{ft}$. Applying the newest rating, SDR 4, the peak discharge at the observed stage without application of a shift would be $652 \mathrm{ft}^{3} / \mathrm{s}$, about the same as the discharge measured 15 minutes later when the stage was $0.80 \mathrm{ft}$ lower.

The peak discharge for the June 26, 2007 event computed without a shift would be correct only if the measured discharge were erroneously high or the drop in stage was the result of the reduction in flow from the storm drain under the bridge rather than a reduction in discharge in the creek. Both conditions are possible. Measurement uncertainty is addressed later in this report. Regarding the effect of the storm-drain discharge, a positive shift is anomalous in this situation because adjusting for the backwater caused by the discharge would require a negative shift, not a positive one. Indeed, the 2007 station analysis (an internal USGS document discussing the year's measurements at a streamgage) notes that "the measurement probably indicates a temporary condition of increased fall due to lack of inflow downstream." The question remains whether the magnitude of this increased fall was as large at the time of the peak as at the time of the measurement. According to the notes from this measurement, eight transect measurements were made with an acoustic Doppler current profiler (ADCP), with a mean discharge of $653 \mathrm{ft}^{3} / \mathrm{s}$ and a standard deviation of $46.7 \mathrm{ft}^{3} / \mathrm{s}$ between 10:47 and 10:55. The gage height fell from 14.14 to $13.55 \mathrm{ft}$ from 10:46 to 10:56, but the transect discharges do not show a significant trend, indicating that at least part of the decrease in stage between the peak and the measurement is unrelated to a decrease in discharge and suggesting that at least part of the shift is unnecessary and the official discharge may be overestimated. On the basis of this analysis, the peak discharge using SDR 4 without a shift being applied (table 4, last column, $652 \mathrm{ft}^{3} / \mathrm{s}$ ) is used as the basis for the comparison of the simulated peak discharge with the confidence interval of the observed peak discharge for this event.

The complete set of observed peak discharge and stage observations for the three streamgages and five events used in this study is presented in table 5 . Comparison of these values confirms that discharge is increasing and stage is decreasing in the downstream direction, as expected. Comparisons with the corresponding simulated values are presented in the "Comparison of Simulated and Observed Peak Discharges and Stages" section.

Table 4. Observed peak discharges at USGS streamgage 03337100 (Boneyard Creek at Lincoln Avenue, Urbana, III.) for storm events analyzed during this study.

[ft, feet; $\mathrm{ft}^{3} / \mathrm{s}$, cubic feet per second; SDR, stage-discharge rating; — , not applicable]

\begin{tabular}{|c|c|c|c|c|c|c|}
\hline $\begin{array}{c}\text { Event date } \\
\text { (month / day / year) }\end{array}$ & $\begin{array}{l}\text { Peak gage height } \\
\text { (ft) }\end{array}$ & $\begin{array}{c}\text { Officiala peak } \\
\text { discharge } \\
\left(\mathrm{ftt}^{3} / \mathbf{s}\right)\end{array}$ & $\begin{array}{l}\text { Identification } \\
\text { number of SDR used } \\
\text { to compute official } \\
\text { peak discharge }\end{array}$ & $\begin{array}{l}\text { Shift applied to } \\
\text { official peak } \\
\text { discharge } \\
\text { (ft) stage }\end{array}$ & $\begin{array}{c}\text { Peak discharge } \\
\text { using official SDR } \\
\text { but no shift } \\
\left(\mathrm{ft}^{3} / \mathbf{s}\right)\end{array}$ & $\begin{array}{c}\text { Peak discharge } \\
\text { using SDR } 4 \\
\text { and no shift } \\
\left(\mathrm{ft}^{3} / \mathrm{s}\right)\end{array}$ \\
\hline $07 / 09 / 2003$ & 17.00 & 797 & 1 & 0.00 & - & 856 \\
\hline $06 / 26 / 2007$ & 14.63 & 714 & 2 & 1.28 & 616 & 652 \\
\hline $06 / 03 / 2008$ & 16.80 & 837 & 3 & 0.00 & - & 842 \\
\hline $07 / 08 / 2008$ & 16.29 & 793 & 3 & 0.00 & - & 793 \\
\hline $09 / 14 / 2008$ & 17.26 & 877 & 3 & 0.00 & - & 878 \\
\hline
\end{tabular}

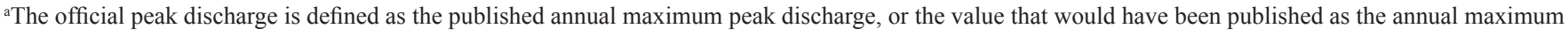
peak, if it had been the largest that water year. 


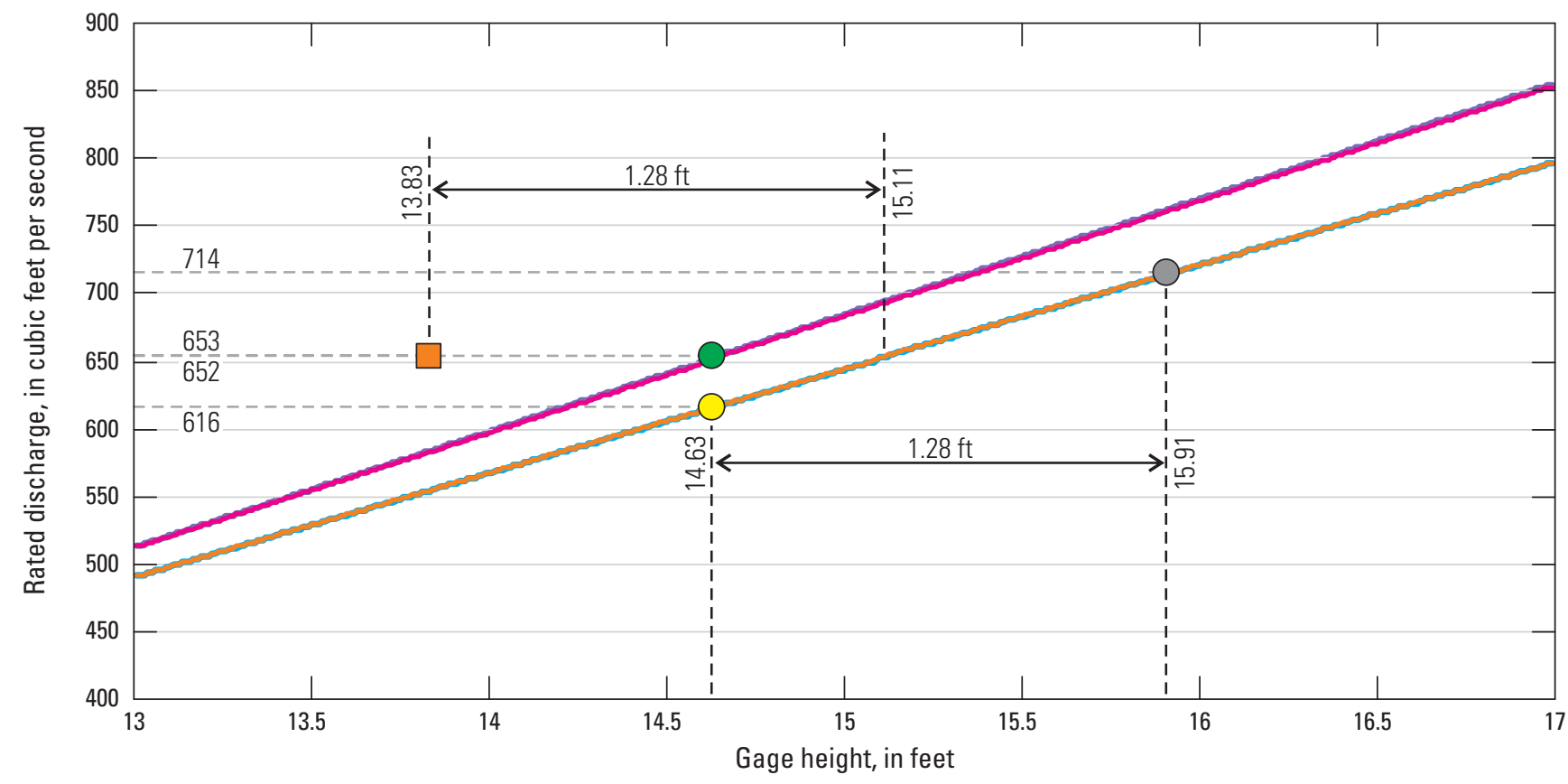

\section{EXPLANATION}

\begin{tabular}{ll}
\hline & Stage-discharge rating 1 \\
& Stage-discharge rating 2 \\
& Stage-discharge rating 3 \\
& Stage-discharge rating 4 \\
& Peak discharge - 1.28 foot shift - rating 2 \\
$\quad$ & Peak discharge - No shift - rating 2 \\
& Peak discharge - rating 4 \\
$\square \quad$ Measured discharge
\end{tabular}

Figure 4. Computation of alternative estimates of peak discharge for the June 26,2007 , high-flow event at USGS streamgage 03337100 (Boneyard Creek at Lincoln Avenue, Urbana, III.).

Table 5. Observed peak discharges and stages at selected streamgages on Boneyard Creek, Urbana, Ill., for storm events analyzed during this study.

[ft, feet; $\mathrm{ft}^{3} / \mathrm{s}$, cubic feet per second; NGVD 29, National Geodetic Vertical Datum of 1929]

\begin{tabular}{ccccccc}
\hline & \multicolumn{2}{c}{ Peak discharge (ft $\left.\mathbf{f t}^{3} \mathbf{s}\right)$} & & \multicolumn{3}{c}{ Peak stage (ft, NGVD 29) } \\
\cline { 2 - 3 } \cline { 6 - 7 } $\begin{array}{c}\text { Event date } \\
\text { (month/day/year) }\end{array}$ & $\begin{array}{c}\text { Campus gage } \\
\text { (station 03337000) }\end{array}$ & $\begin{array}{c}\text { Lincoln Avenue } \\
\text { gage } \\
\text { (station 03337100) }\end{array}$ & & $\begin{array}{c}\text { Campus gage } \\
\text { (station 03337000) }\end{array}$ & $\begin{array}{c}\text { Lincoln Avenue } \\
\text { gage } \\
\text { (station 03337100) }\end{array}$ & $\begin{array}{c}\text { Race Street gage } \\
\text { (station 03337250) }\end{array}$ \\
\hline $07 / 09 / 2003$ & 780 & 856 & & 712.59 & 711.00 & 705.68 \\
$06 / 26 / 2007$ & 571 & 652 & & 710.76 & 708.63 & 703.41 \\
$06 / 03 / 2008$ & 727 & 842 & & 712.13 & 710.80 & 705.06 \\
$07 / 08 / 2008$ & 686 & 793 & & 711.78 & 710.29 & 705.26 \\
$09 / 14 / 2008$ & 812 & 878 & & 712.85 & 711.26 & 705.30 \\
\hline
\end{tabular}




\section{Discharge-Uncertainty Analysis}

A modification of the method proposed by Dymond and Christian (1982) was selected for estimating the observed discharge uncertainty at Lincoln Avenue. The quantity to be computed is $\sigma_{Q}^{2}$, the variance of an instantaneous discharge value computed by using a stage-discharge rating. The original method of Dymond and Christian was developed to apply under the following conditions: (1) discharges are estimated by using a stage-discharge rating curve that can be approximated with the power-law functional form $Q=a^{\prime}\left(h-h_{0}\right)^{b^{\prime}}$, where $Q$ is discharge, $h$ is stage, $h_{0}$ is stage when discharge is zero (assumed known), and $a^{\prime}$ and $b^{\prime}$ are parameters to be estimated by using ordinary least-squares (OLS) regression after taking logs of both sides of the rating curve; and (2) ratingcurve shifts are random and not persistent between events. The method considers uncertainty (or "error") resulting from three main sources: (1) error in the measurement of stage, (2) error resulting from "ignoring all physical parameters other than [stage]," which will be termed "model error" herein, and (3) error in the rating curve.

Strictly speaking, the presence of stage-measurement error in an OLS framework is not statistically valid, because the effect of measurement error on the $\mathrm{x}$-axis of a regression requires a generalized form of least-squares regression, an "errors-in-variables model" (Brent Troutman, U.S. Geological Survey, written commun., 2010; Draper and Smith, 1981; Fuller, 1987). Draper and Smith (1981, p. 122-125) and Fuller (1987, p. 1-5), however, show that the effect of such errors is proportional to the ratio between the $\mathrm{x}$-axis variable's error and its range. In the present case, the stage-measurement error is about $0.04 \mathrm{ft}$ while the range of stages being considered is 3-7 ft, implying a very small effect, so the uncertainty computation in the OLS framework as presented by Dymond and Christian (1982) is retained as an approximation.

In the present application, the following modification of the Dymond and Christian (1982) method is made: because the rating curve is well approximated by a straight line, that is, $Q=a^{\prime}\left(h-h_{0}\right)^{b^{\prime}}$ with $b^{\prime}=1$, the rating-curve regression employs the functional form $Q=a+b h$. With this modification, the uncertainty estimation method can be expressed as

$$
\sigma_{Q}^{2}=\sigma_{Q_{\Delta h}}^{2}+\sigma_{\theta}^{2}+\sigma_{m r}^{2}
$$

where $\sigma_{Q_{\Delta h}}^{2}$ is the discharge uncertainty resulting from stagemeasurement uncertainty, $\sigma_{\theta}^{2}$ is model error variance, and $\sigma_{m r}^{2}$ is rating-curve error variance.

The computation of each term in equation 1 will now be discussed. The discharge uncertainty resulting from stagemeasurement uncertainty is given by

$$
\sigma_{Q_{\Delta h}}^{2}=b^{2} \sigma_{\Delta h}^{2}
$$

where $b$ is, as before, the slope of the rating curve and $\sigma_{\Delta h}^{2}$ is the variance of the stage-measurement error $\Delta h$. An examination of the gage-height corrections given in the station analyses for Boneyard Creek at Lincoln Avenue shows that a good estimate, $S_{\Delta h}$, of the stage-measurement error $\left(\sigma_{\Delta h}\right)$ would be $0.04 \mathrm{ft}$, giving a stage-measurement error variance estimate $S_{\Delta h}^{2}$ of $0.04^{2}=0.0016 \mathrm{ft}^{2}$.

The model error variance $\sigma_{\theta}^{2}$ is computed as

$$
\sigma_{\theta}^{2}=\max \left[\sigma_{\varepsilon}^{2}-\sigma_{Q_{\Delta h}}^{2}-\sigma_{\Delta Q_{m}}^{2}, 0\right]
$$

where $\sigma_{\epsilon}^{2}$ is the variance of the error term $(\varepsilon)$ of the regression equation and $\Delta Q_{m}$ is the discharge-measurement error; that is, the uncertainty in the measured discharges used to construct the rating curve. The maximum function max [] is used in equation 3 to prevent the value of the model error variance $\sigma_{\theta}^{2}$ from becoming negative when the sum of the dischargemeasurement error variance $\sigma_{\Delta Q_{m}}^{2}$ and the stage-measurement error contribution $\sigma_{Q_{\Delta h}}^{2}$ exceeds the regression error variance $\sigma_{\epsilon}^{2}$. If this does occur, it also suggests some problem because it would imply that there is no model error. Most likely in such a case, the discharge-measurement error will have been overestimated, assuming stage-measurement error contribution is small.

The regression error term $\sigma_{\epsilon}^{2}$ is estimated by the squared standard error $S_{\varepsilon}^{2}$ of the regression,

$$
\sigma_{\varepsilon}^{2} \approx S_{\varepsilon}^{2}=\frac{1}{n-2} \sum_{i=1}^{n}\left(y_{i}-\hat{y}_{i}\right)^{2}
$$

where $y_{i}, i=1,2, \ldots, n$ are the observed $y$ values (the measured discharges) and $\hat{y}_{i}$ are $y$ values predicted by the regression equation; that is, $\hat{y}_{i}=a+b x_{i}$, where $x_{i}$ are the observed stages (that is, $x_{i}=h_{i}$ ).

The other component, rating-curve error $\sigma_{m r}^{2}$, is estimated by using the standard result for the uncertainty of the estimation of the mean value of $Y$ given a certain value, $X_{0}$, of $X$ in OLS regression (see, for example, Draper and Smith, 1981, equations 1.4.9-1.4.10):

$$
\sigma_{m r}^{2} \approx S_{m r}^{2}=S_{\varepsilon}^{2}\left[\frac{1}{n}+\frac{\left(X_{0}-\bar{X}\right)^{2}}{\sum_{i=1}^{n}\left(X_{i}-\bar{X}\right)^{2}}\right]
$$

Combining the model error and rating-curve error terms (equations 1 and 3 ) gives the uncertainty of a given value of discharge $\sigma_{Q}^{2}$ estimated from the stage-discharge rating as

$$
\sigma_{Q}^{2} \approx S_{Q}^{2}=S_{Q_{\Delta h}}^{2}+\max \left[S_{\varepsilon}^{2}-S_{Q_{\Delta h}}^{2}-S_{\Delta Q_{m}}^{2}, 0\right]+S_{m r}^{2}
$$

To help in interpretation of this result, notice that if $S_{\varepsilon}^{2}>S_{\Delta Q_{m}}^{2}+S_{Q_{\Delta h}}^{2}$, the maximum function may be removed and equation 6 may be written as

$$
S_{Q}^{2}=S_{\varepsilon}^{2}\left[1+\frac{1}{n}+\frac{\left(X_{0}-\bar{X}\right)^{2}}{\sum_{i=1}^{n}\left(X_{i}-\bar{X}\right)^{2}}\right]-S_{\Delta Q_{m}}^{2}
$$


Note that the first term is the uncertainty of an individual (as opposed to the mean) predicted value at $X_{0}$ in OLS regression for the usual case in which the error term in prediction is the same as in the observations (in other words, there is no measurement error) (Draper and Smith, 1981, equation 1.4.11; Helsel and Hirsch, 2002, p. 241). Because the discharge-measurement error will not be present in the predicted value, its variance estimate $S_{\Delta Q_{m}}^{2}$ is subtracted.

\section{Uncertainty of the Observed Peak Discharge on Boneyard Creek at Lincoln Avenue}

The discharge uncertainty methodology described above relies on three computations: an estimate of the effect of stage-measurement error, a rating-curve regression and an estimation of measurement uncertainty. The results of these computations and their combination to obtain the uncertainty of the overall observed peak discharge are described in this section. Because the discharges at Lincoln Avenue are of primary importance for the evaluation of the design model, the uncertainty of the observed peak discharge are computed for that streamgage only.

\section{Rating-Curve Regression}

Two factors were considered in deciding which measurements to use in computing the rating curves that in turn were used to compute discharge-estimation uncertainty. One is that the higher discharges are of interest. The other is that two modifications were made to the channel near the gage during its period of record: (a) the cofferdam upstream from the gage was removed with the completion of the UIUC channel improvements in May 2003, and (b) a new channel control was installed in September 23, 2004 (a 6- by 6-in. angle iron bolted to the channel bottom). The latter modification would imply that only measurements after that date should be considered; however, for higher discharges, the installation of the angle iron may have little effect because the hydraulic control is downstream from it (Kevin K. Johnson, U.S. Geological Survey, oral commun., 2010). Linear rating-curve regressions for two different groups of measurements were used to compute discharge-estimation uncertainty and are presented here. The choice of these groups of measurements was based on the timing of the two channel modifications and the objective of rating high flows.

The first group consists of measurements between June 2003 and September 2009 that were made when the depth at the gage was greater than $5 \mathrm{ft}$ (equivalent to gage heights greater than $12 \mathrm{ft}$ ). It comprises 23 values from events between June 11, 2003, and May 13, 2009, and discharges between 378 and $704 \mathrm{ft}^{3} / \mathrm{s}$. For this range of dates and depths, it is assumed that the low-flow channel control installed in September 2004 has little effect for such relatively high flows. For this group of measurements, the slope of the rating curve, $b$, is about $80.5\left(\mathrm{ft}^{3} / \mathrm{s}\right) / \mathrm{ft}$, and the regression standard error, $S_{\varepsilon}$, is about $62 \mathrm{ft}^{3} / \mathrm{s}$ (fig. $5 A$ ). The residuals around this rating curve as a function of time are shown in figure $5 B$. The residuals plot shows a few cases where multiple measurements were made during the same event. The wide range of residuals during the same event suggests a looped rating curve; that is, a curve for which the relation between stage and discharge is not unique. Although some sediment moves through this channel, the presence of a concrete channel bottom means that the looping is not the result of scouring and filling but instead results from hydraulic effects, including the backwater effect from discharge of the large storm drain into the creek under the Lincoln Avenue bridge.

The other rating-curve regression considered here consists of measurements from water years 2005 through 2009 (that is, October 1, 2004 through September 30, 2009) when the depth at the gage was greater than $1 \mathrm{ft}$ (equivalent to gage heights greater than $8 \mathrm{ft}$ ). This group of measurements comprises 29 values from events between October 18, 2004, and May 13, 2009, and discharges between 57.6 and $704 \mathrm{ft}^{3} / \mathrm{s}$. Because this range of dates includes only the period after the installation of the channel control in September 2004, a greater range of depths is included. According to this group of measurements, the slope of the rating curve, $b$, is about $86.7\left(\mathrm{ft}^{3} / \mathrm{s}\right) / \mathrm{ft}$, and the regression standard error, $S_{\varepsilon}$, is about $56 \mathrm{ft}^{3} / \mathrm{s}$ (fig. 6A). This regression also shows what is only suggested in figure 5 : reduced scatter at the midrange of flows, approximately 250 to $400 \mathrm{ft}^{3} / \mathrm{s}$. The cause of this phenomenon is not clear, but one important implication is that the somewhat smaller value of $S_{\varepsilon}$ obtained for this rating-curve regression may not be not as characteristic of the higher flows as the result from the regression shown previously in figure 5. Because of this concern about the characterization of the uncertainty of the higher flows that are of primary interest in this study, the final results of the study use the first rating curve, shown in figure 5.

The residuals around the second rating curve as a function of time are shown in figure $6 B$. This plot, like figure $5 B$, shows a few times when multiple measurements were made during the same event (in fact, it includes the measurements shown in figure 5 over their common period but adds some additional measurements, especially during summer 2008). 

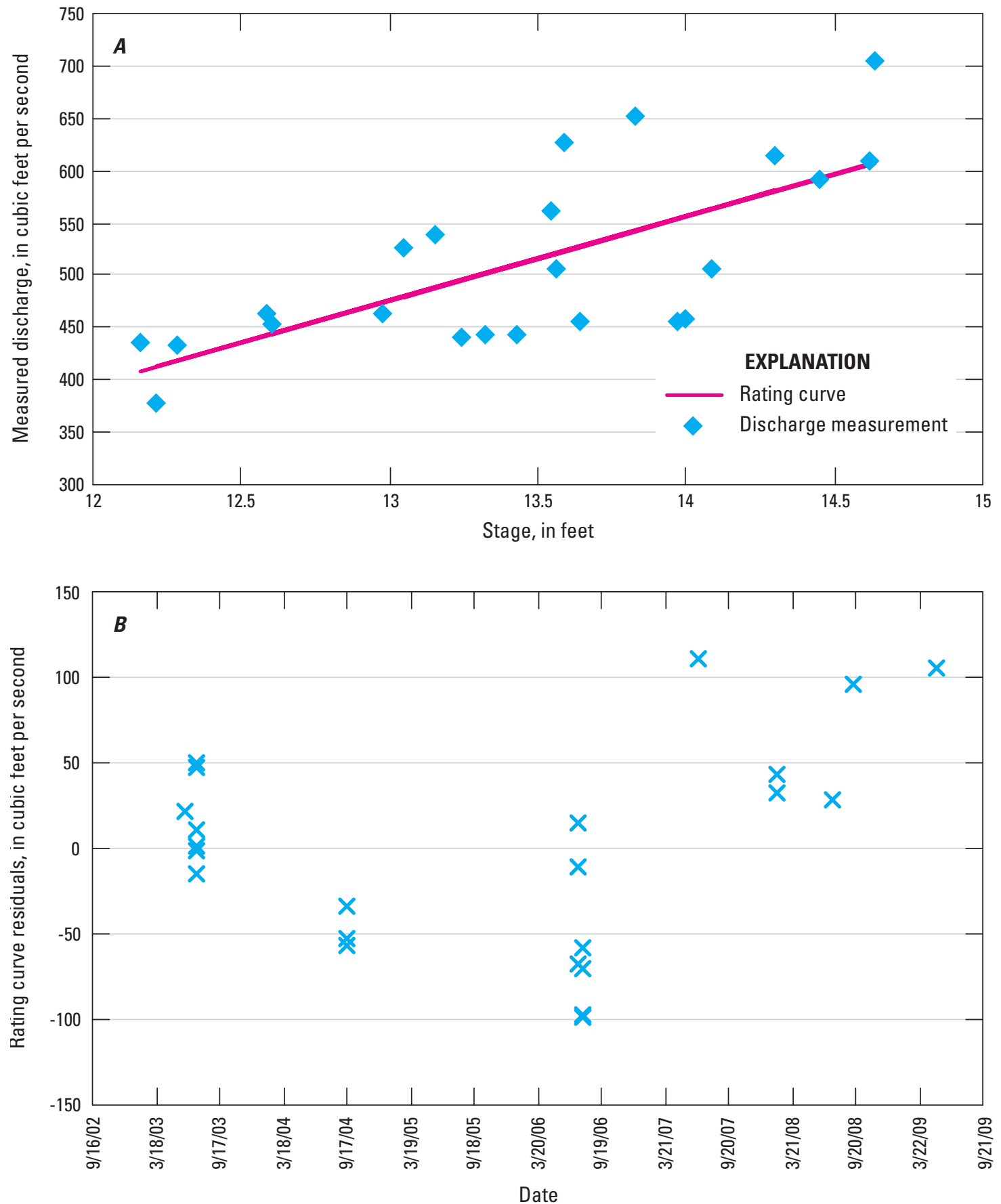

Figure 5. Stage-discharge rating-curve regression for USGS streamgage 03337100 (Boneyard Creek at Lincoln Avenue, Urbana, III.) using measurements obtained between June 2003 and September 2009 when the depth of flow was greater than 5 feet (gage height greater than 12 feet). $A$, Scatterplot of data and fitted line. $B$, Residuals as a function of time. The parameters obtained are the slope, $b=80.49$ cubic feet per second per foot, and the regression standard error, $S_{\varepsilon}=62.2$ cubic feet per second. 

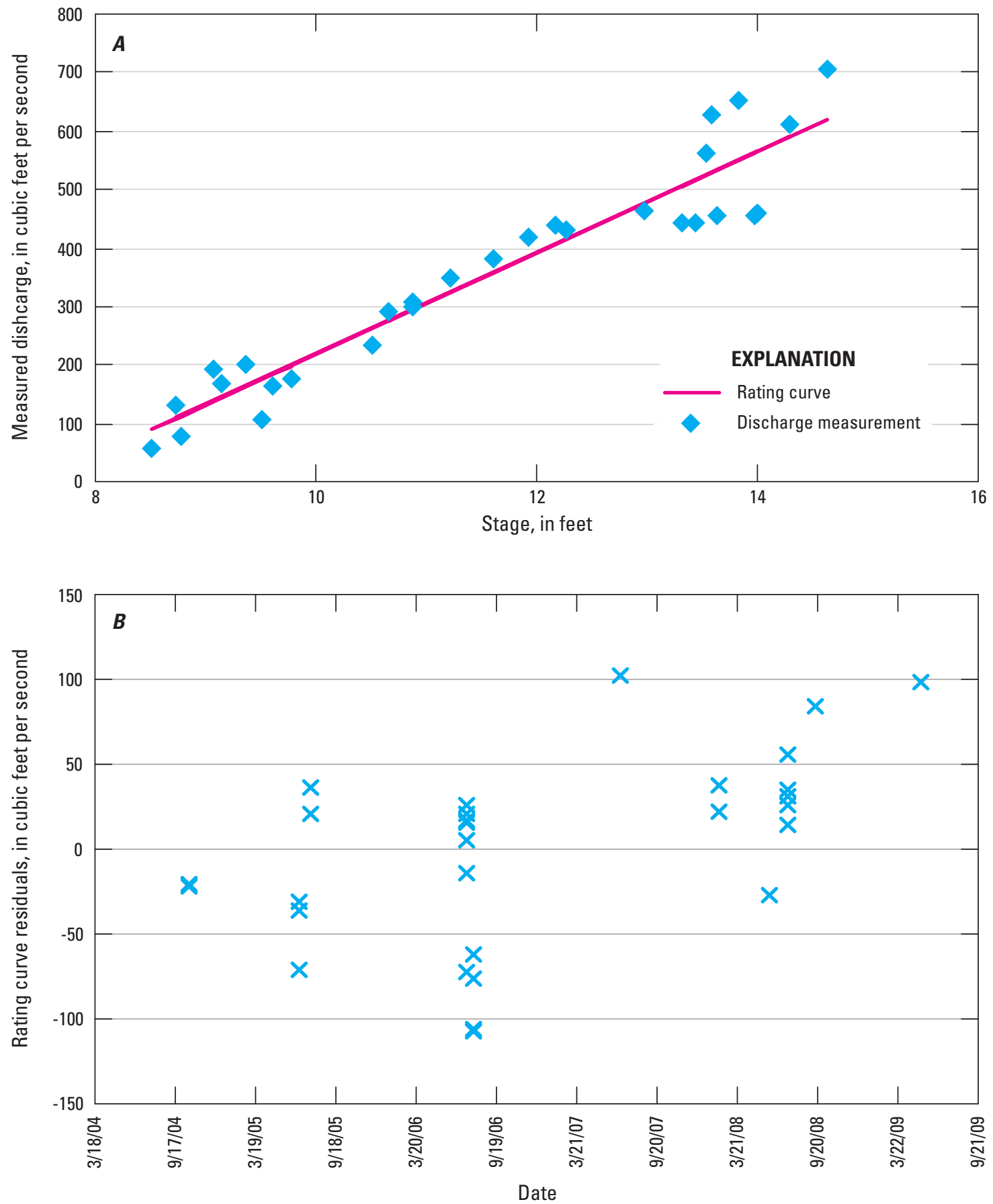

Figure 6. Stage-discharge rating-curve regression for USGS streamgage station 03337100 (Boneyard Creek at Lincoln Avenue, Urbana, III.) using measurements obtained during water years 2005 through 2009 when the depth of flow was greater than 1 foot (gage height greater than 8 feet). $A$, Scatterplot of data and fitted line. $B$, Residuals as a function of time. The parameters obtained are the slope, $b=86.68$ cubic feet per second per foot, and regression standard error, $S_{\varepsilon}=56.3$ cubic feet per second. 


\section{Measurement Error Computation}

The discharge measurements in the Boneyard Creek at Lincoln Avenue rating curve for high flows were generally obtained by using a Rio Grande broadband ADCP manufactured by Teledyne RD Instruments (RDI). Estimates of the measurement error for four ADCP measurements were computed by Luke Fitzgerald of the Office of Surface Water (OSW) of the USGS, under the supervision of Kevin Oberg, also of OSW, using a spreadsheet provided by Randy Marsden of RDI (written commun., 2004, 2005, 2007, 2008, 2009). The results of these computations are given in table 6 , which show values of 2.7 to 3 percent for three of the measurements, including the largest two discharges, and a somewhat larger value of 3.65 percent for the measurement with the least discharge, most shallow flow depth, and smallest fraction of directly measured discharge. (The remainder - the flow in the boundary regions at the top and bottom of the water column and along the sides of the channel-cannot be measured directly with the ADCP but instead is estimated by extrapolation from the measured values next to these areas). This measurement also had a significant percentage of invalid depth cells ${ }^{2}$, which are those depth cells in the measured area for which the instrument could not resolve meaningful information.

The uncertainty values given in table 6 for these selected measurements on Boneyard Creek may be compared with the values appearing in general tables, for example, table 13.3 of Herschy (1999), which gives 5 percent as the "attainable" (minimum) uncertainty in discharge measurement at the 95-percent level, which is equivalent to a standard deviation of 2.5 percent. These values also may be compared with ADCP uncertainty estimates based on comparison with reference measurements (current-meter measurements, rated discharges, or rated discharges adjusted by using currentmeter measurements), such as are given in Morlock (1996) and Oberg and Mueller (2007). In Morlock's study (1996), 31 ADCP measurements made with an early model of an RDI ADCP at 12 sites were compared. At 10 of the 12 sites, the magnitudes of all the differences were less than 5 percent. At the two remaining sites, the magnitudes of the differences were approximately 7 percent when compared with rated discharges, but these became 5.1 percent or less when the rated discharges were adjusted by using current-meter measurements made concurrently with the ADCP measurements, with a standard deviation of 2.7 percent. (This standard deviation value is not from Morlock (1996) but was computed for this study). Only one site used in Morlock's study (1996) had a reference discharge less than $2,000 \mathrm{ft}^{3} / \mathrm{s}$; at that site, the reference discharge was $768 \mathrm{ft}^{3} / \mathrm{s}$, and the ADCP measurements were 758 and $745 \mathrm{ft}^{3} / \mathrm{s}$, yielding differences of -1.3 and -3.0 percent.

In Oberg and Mueller (2007), results from laboratory (tow-tank) and field measurements made with several different ADCP models are given. Here we concentrate on the 61 field measurements at 16 sites Oberg and Mueller obtained by using the RDI Rio Grande in Water Mode 12, for which the reference discharges ranged from 69.6 to $6,850 \mathrm{ft}^{3} / \mathrm{s}$. These measurements were made with the same instrument model and water mode as used in the Boneyard Creek measurements listed in table 6 . For these measurements, differences between the ADCP and reference discharges ranged from -15.9 to 8.7 percent, with a mean of -0.14 percent (not statistically different from zero). The standard deviation of the percent differences was 5.8, more than double the values from Herschy (1999) and Morlock (1996).In Oberg and Mueller (2007), results from laboratory (tow-tank) and field measurements made with several different ADCP models are given. Here we

\footnotetext{
${ }^{2} \mathrm{~A}$ depth cell is a subdivision of the reflected ADCP signal, corresponding to a position in the vertical of the measured transect.
}

Table 6. Results of discharge measurement uncertainty analysis on selected measurements at USGS streamgage 03337100 (Boneyard Creek at Lincoln Avenue, Urbana, III.).

$\left[\mathrm{ft}^{3} / \mathrm{s}\right.$, cubic feet per second; \%, percent]

\begin{tabular}{|c|c|c|c|c|c|c|c|}
\hline $\begin{array}{c}\text { Date of } \\
\text { measurement }\end{array}$ & $\begin{array}{l}\text { Measurement } \\
\text { number }\end{array}$ & $\begin{array}{c}\text { Measured } \\
\text { discharge } \\
\left(\mathrm{ft}^{3} / \mathrm{s}\right)\end{array}$ & $\begin{array}{l}\text { Flow depth } \\
\text { (feet), for stage } \\
\text { of zero flow: } \\
7.00 \text { feet }\end{array}$ & $\begin{array}{l}\text { Fraction of } \\
\text { directly measured } \\
\text { discharge } \\
(\%)\end{array}$ & $\begin{array}{l}\text { Fraction of } \\
\text { invalid depth } \\
\text { cells } \\
(\%)\end{array}$ & $\begin{array}{c}\text { Error standard } \\
\text { deviation } \\
(\%)\end{array}$ & $\begin{array}{c}\text { Error standard } \\
\text { deviation } \\
\left(\mathrm{ft}^{3} / \mathbf{s}\right)\end{array}$ \\
\hline June 3, 2008 & 106 & 234 & 3.50 & 32 & 0 & 2.70 & 6.3 \\
\hline July 12, 2008 & 108 & 170 & 2.15 & 22 & 43 & 3.65 & 6.2 \\
\hline May 13, 2009 & 117 & 628 & 6.59 & 49 & 0 & 2.93 & 18.4 \\
\hline
\end{tabular}


concentrate on the 61 field measurements at 16 sites Oberg and Mueller obtained by using the RDI Rio Grande in Water Mode 12, for which the reference discharges ranged from 69.6 to $6,850 \mathrm{ft}^{3} / \mathrm{s}$. These measurements were made with the same instrument model and water mode as used in the Boneyard Creek measurements listed in table 6. For these measurements, differences between the ADCP and reference discharges ranged from -15.9 to 8.7 percent, with a mean of -0.14 percent (not statistically different from zero). The standard deviation of the percent differences was 5.8, more than double the values from Herschy (1999) and Morlock (1996).

In interpreting the results of such comparisons between ADCP and reference discharges as are given in both Morlock (1996) and Oberg and Mueller (2007), it should be kept in mind that the reference discharges also are subject to error, so the stated percent differences are likely to be larger on average than what would result from comparison to the true value. A quantitative estimate of this effect can be obtained by assuming that the observed value is the difference between two uncorrelated random variables, say, $X_{1}$ and $X_{2}$, with a common variance $\sigma_{X}^{2}$. Then the variance $\sigma_{Y}^{2}$ of the difference $Y=X_{1}-X_{2}$ is $\sigma_{Y}^{2}=2 \sigma_{X}^{2}$, and the standard deviation is $\sigma_{Y}=\sqrt{2} \sigma_{X}$, suggesting a standard deviation inflation factor of $\sqrt{2}$. Applying this model to the Water Mode 12 RDI Rio Grande measurements from Oberg and Mueller (2007), the error standard deviation resulting from ADCP errors alone would be 5.8/ $\sqrt{2}=4.1$ percent. If the errors were positively correlated, the inflation factor would be larger, whereas if they were negatively correlated, it would be smaller.

Summarizing the results from these previous studies of ADCP error, Herschy (1999) indicated that under ideal conditions the ADCP error standard deviation might be 2.5 percent, and the field study by Morlock (1996) attained a similar result (2.7 percent) without adjustment for a variance inflation factor, whereas the larger study of Oberg and Mueller (2007) indicated an error standard deviation without variance inflation adjustment of 5.8 percent and 4.1 percent after adjustment with a roughly estimated variance inflation factor of $\sqrt{2}$. Given the large fraction of the unmeasured area when using an ADCP in a small stream such as Boneyard Creek, matching the minimum ADCP error seems unlikely (Kevin Oberg, U.S. Geological Survey, oral commun., 2010). Therefore, to include both the increase in percent error for smaller discharges and the possibility that the values in table 6 are too small, the estimates of computed discharge uncertainty are obtained using a minimum value of 2.5 percent and larger assumed values of 5 and 7.5 percent.

\section{Discharge-Computation Uncertainty}

The results of applying the methodology for estimation of discharge-computation uncertainty presented previously, as adapted from Dymond and Christian (1982), are presented in table 7 . These results were obtained with the rating-curve regressions shown in figures 5 and 6 at a discharge of $700 \mathrm{ft}^{3} / \mathrm{s}$. These results show, first of all, that the effect of stage-measurement uncertainty is indeed small, at about $3.2-3.5 \mathrm{ft}^{3} / \mathrm{s}$, compared to the other terms, which are on the order of tens of cubic feet per second. The next two columns give the uncertainties arising from the rating-curve regression alone: the regression standard error, $S_{\varepsilon}$, and the rating-curve uncertainty, $S_{m r}$, at the stage corresponding to the given discharge. The remaining columns depend on the measurement uncertainty, for which the three values $2.5,5$, and 7.5 percent were used. Using these measurement errors allows computation of the model error, $\mathrm{S}_{\theta}$ (by using equation 3), given in the next column and then the overall instantaneous discharge computation uncertainty, $S_{Q}$ (by using equation 6), given in the next-to-last column. Because the model error is positive, the instantaneous-discharge-computation uncertainty is equivalently also given by equation 7 . Nevertheless, the model-error component of discharge-computation error decreases with measurement error, as equation 6 shows. Finally, the last column gives 95-percent confidence intervals for the instantaneous-discharge-computation uncertainty estimated as $Q \pm 2 S_{Q}$. These intervals range from 62 to almost $150 \mathrm{ft} 3 / \mathrm{s}$ and imply (with 95-percent certainty) that when the instantaneous discharge at the Boneyard Creek at Lincoln Avenue gage is computed as $700 \mathrm{ft}^{3} / \mathrm{s}$, it lies within a minimum range of 638 to $762 \mathrm{ft}^{3} / \mathrm{s}$ if the measurement uncertainty is 7.5 percent and the appropriate rating-curve regression to use is for water years 2005-9 and a flow depth greater than $1 \mathrm{ft}$ (bottom row). Table 7 further shows that a computed discharge of $700 \mathrm{ft}^{3} / \mathrm{s}$ lies within a maximum range of 552 to $848 \mathrm{ft}^{3} / \mathrm{s}$ if the measurement uncertainty is 2.5 percent and the appropriate regression to use is for June 2003 through September 2009 and a flow depth greater than $5 \mathrm{ft}$ (top row). 
Table 7. Instantaneous-discharge-computation uncertainty components for a discharge of 700 cubic feet per second for USGS streamgage 03337100 (Boneyard Creek at Lincoln Avenue, Urbana, III.).

[WY, water year; $\mathrm{ft}^{3} / \mathrm{s}$, cubic feet per second; $\%$, percent]

\begin{tabular}{|c|c|c|c|c|c|c|c|c|}
\hline $\begin{array}{l}\text { Rating-curve } \\
\text { regression } \\
\text { conditions }\end{array}$ & $\begin{array}{c}\text { Discharge- } \\
\text { computation error } \\
\text { from stage } \\
\text { measurement error, } \\
S_{a_{\Delta h}} \\
\left(\mathrm{ft}^{3} / \mathrm{s}\right)\end{array}$ & $\begin{array}{c}\text { Regression } \\
\text { error, } S_{\varepsilon} \\
\left(\mathrm{ft}^{3} / \mathbf{s}\right)\end{array}$ & $\begin{array}{c}\text { Rating-curve } \\
\text { uncertainty, } \boldsymbol{S}_{m r} \\
\left(\mathrm{ft}^{3} / \mathbf{s}\right)\end{array}$ & $\begin{array}{c}\text { Discharge- } \\
\text { measurement } \\
\text { error, } S_{\Delta a_{m}} \\
\left(\mathrm{ft}^{3} / \mathrm{s}\right)\end{array}$ & $\begin{array}{l}\text { Model error, } S_{\theta} \\
\quad\left(\mathrm{ft}^{3} / \mathrm{s}\right)\end{array}$ & $\begin{array}{c}\text { Discharge- } \\
\text { computation } \\
\text { error, } S_{a} \\
\left(\mathrm{ft}^{3} / \mathrm{s}\right)\end{array}$ & $\begin{array}{c}\text { Discharge- } \\
\text { computation error } \\
\text { as a fraction of } \\
\text { discharge, } S_{Q} / Q \\
(\%)\end{array}$ & $\begin{array}{l}\text { Approximate } 95 \% \\
\text { confidence interval } \\
\text { of discharge } \\
\text { computation, } 2 S_{a} \\
\left(\mathrm{ft}^{3} / \mathrm{s}\right)\end{array}$ \\
\hline \multicolumn{9}{|c|}{ Discharge measurement error $=2.5$ percent } \\
\hline $\begin{array}{c}\text { WY 2002-2009, } \\
\text { depth }>5 \mathrm{ft} \\
\text { (Figure 5) }\end{array}$ & 3.22 & 62.2 & 43.5 & 17.5 & 59.6 & 73.9 & 10.6 & \pm 148 \\
\hline $\begin{array}{l}\text { WY 2005-09, } \\
\text { depth }>1 \mathrm{ft} \\
\text { (Figure 6) }\end{array}$ & 3.47 & 56.3 & 23.6 & 17.5 & 53.4 & 58.5 & 8.4 & \pm 117 \\
\hline \multicolumn{9}{|c|}{ Discharge measurement error $=5$ percent } \\
\hline $\begin{array}{l}\text { WY 2002-2009, } \\
\text { depth }>5 \mathrm{ft} \\
\text { (Figure 5) }\end{array}$ & 3.22 & 62.2 & 43.5 & 35.0 & 51.3 & 67.4 & 9.6 & \pm 135 \\
\hline $\begin{array}{l}\text { WY 2005-09, } \\
\text { depth }>1 \mathrm{ft} \\
\text { (Figure 6) }\end{array}$ & 3.47 & 56.3 & 23.6 & 35.0 & 44.0 & 50.0 & 7.1 & \pm 100 \\
\hline \multicolumn{9}{|c|}{ Discharge measurement error $=7.5$ percent } \\
\hline $\begin{array}{l}\text { WY 2002-2009, } \\
\text { depth }>5 \mathrm{ft} \\
(\text { Figure 5) }\end{array}$ & 3.22 & 62.2 & 43.5 & 52.5 & 33.2 & 54.8 & 7.8 & \pm 110 \\
\hline $\begin{array}{l}\text { WY 2005-09, } \\
\text { depth }>1 \mathrm{ft} \\
\text { (Figure 6) }\end{array}$ & 3.47 & 56.3 & 23.6 & 52.5 & 20.1 & 31.2 & 4.5 & \pm 62.4 \\
\hline
\end{tabular}


The components of the uncertainty as a function of discharge for measurement uncertainties of 5 and 7.5 percent based on the rating curve regression computed from depths greater than $5 \mathrm{ft}$ are presented in figure 7 . This figure shows two important features: (a) the regression-based rating-curve error has a minimum at about $500 \mathrm{ft}^{3} / \mathrm{s}$ (this occurs at the discharge corresponding to the average stage, as can be seen in equation 5), which leads to a minimum in the computed discharge error, and (b) the model error decreases with discharge when the measurement error is a constant percentage of the discharge, as it must, according to equation 3; here, for a measurement uncertainty of 7.5 percent, the condition where the measurement error variance $\sigma_{\Delta Q_{m}}^{2}$ exceeds the regression error variance $\sigma_{\epsilon}^{2}$ such that the model error variance is taken as zero (see equation 3 ) occurs for discharges greater than about $820 \mathrm{ft}^{3} / \mathrm{s}$, suggesting the measurement error has been overestimated, at least in this range of discharge (or the regression error is heteroscedastic). Given this anomalous behavior, assuming a 5-percent measurement error seems preferable. Although a 5-percent measurement error could be an underestimate, at the same time, because of the influence of the backwater caused by the discharge of the storm drain under the Lincoln Avenue bridge, the model error is not likely to be zero even if the true rating is linear. A complete resolution of this issue would require not only an improved method of estimating the ADCP measurement error but also more measurements at the streamgage to refine the structure of the rating-curve residuals, both of which are outside the scope of this study. As a result, the final results presented in this report reflect a compromise assumption that the measurement error is 5 percent.
Discharge-computation-uncertainty results for discharges from 300 to $900 \mathrm{ft}^{3} / \mathrm{s}$ given in figures 8 and 9 illustrate the sensitivity of the discharge uncertainty to the discharge value. Figure 8 indicates that the uncertainty of the computed discharge, $S_{Q}$, is $80 \mathrm{ft}^{3} / \mathrm{s}$ at a discharge of $300 \mathrm{ft}^{3} / \mathrm{s}$ and decreases to a minimum about $60 \mathrm{ft}^{3} / \mathrm{s}$ at a discharge of about $510 \mathrm{ft}^{3} / \mathrm{s}$ for measurement errors of 2.5 and 5 percent, whereas the minimum occurs at about $590 \mathrm{ft}^{3} / \mathrm{s}$ and has a value of about $48 \mathrm{ft}^{3} / \mathrm{s}$ for measurement error of 7.5 percent (final results in this report assume a measurement error of 5 percent; results for measurement errors of 2.5 and 7.5 percent are given for the purpose of illustration). The existence of minimums in the discharge-uncertainty result arises from the rating-curve uncertainty, $S_{m r}$, which increases away from $511.5 \mathrm{ft}^{3} / \mathrm{s}$, the average of the data used in the regression, and the differences in the locations of the minimums results from differences in the shapes of the model error variance term (fig. 7). After the minimum, the discharge uncertainty increases again, reaching values of $80-100 \mathrm{ft}^{3} / \mathrm{s}$ at a discharge of $900 \mathrm{ft}^{3} / \mathrm{s}$. The computed discharge uncertainty is only weakly dependent on the measurement error for the values of 2.5 and 5 percent, with a slightly smaller value for the larger measurement error, as the results in table 7 already showed, whereas a larger decrease is evident for a measurement error of 7.5 percent. In figure 9, the discharge-computation uncertainty is shown as an estimated 95-percent confidence band (computed as $Q \pm 2 S_{Q}$, where the $S_{Q}$ values are as shown in figure 8 for a measurement error of 5 percent). The observed peak discharges and their 95 -percent confidence intervals using the values from figure 9 are given in numerical form in table 8 . 

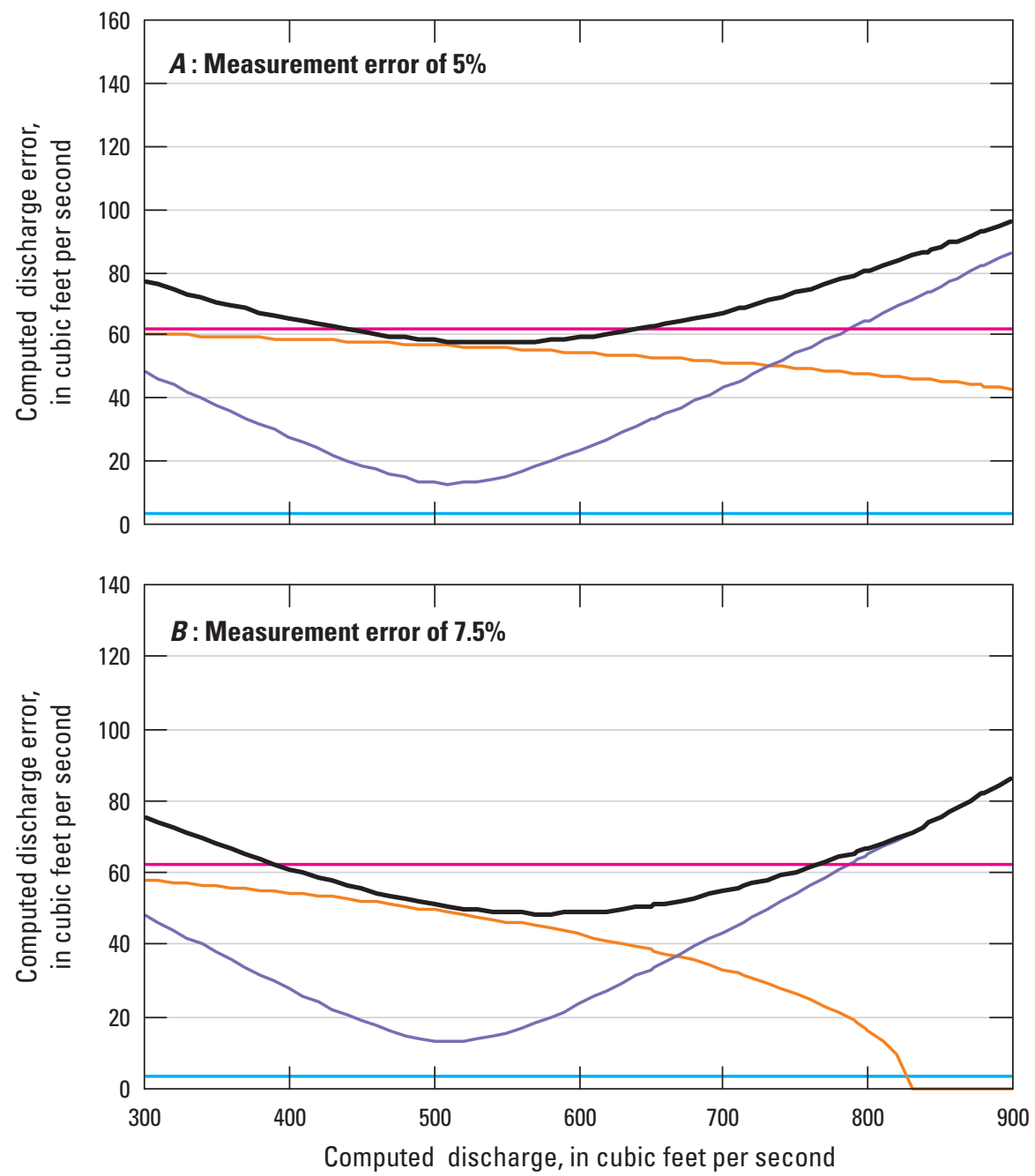

EXPLANATION

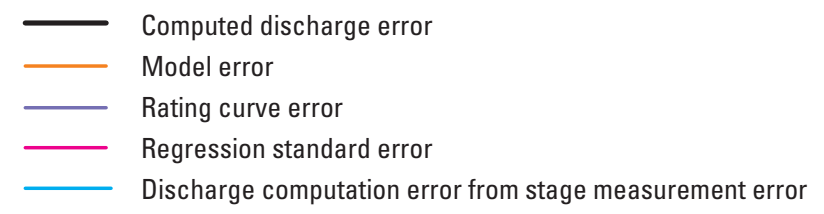

Figure 7. Components of uncertainty of computed discharge as a function of discharge for USGS streamgage 03337100 (Boneyard Creek at Lincoln Avenue, Urbana, III.), using measurements obtained from June 2003 through September 2009 when the depth of flow was greater than 5 feet. $A$, Measurement error of 5 percent. $B$, Measurement error of 7.5 percent. Measurements included in the rating-curve regression range from 378 to 704 cubic feet per second. 


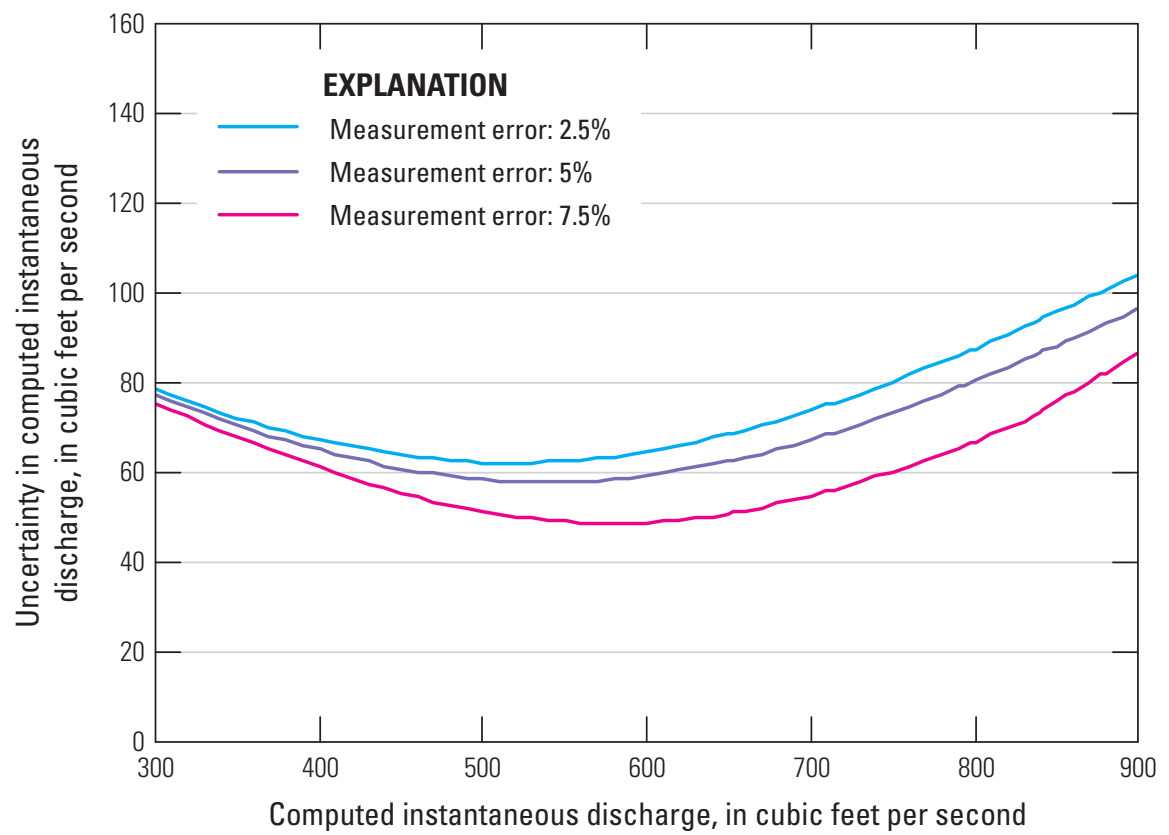

Figure 8. Uncertainty of computed discharge expressed as a standard deviation at USGS streamgage 03337100 (Boneyard Creek at Lincoln Avenue, Urbana, III.), using measurements obtained from June 2003 through September 2009 when the depth of flow was greater than 5 feet. Curves reflect varied assumptions on measurement uncertainty. Measurements included in the rating-curve regression range from 378 to 704 cubic feet per second.

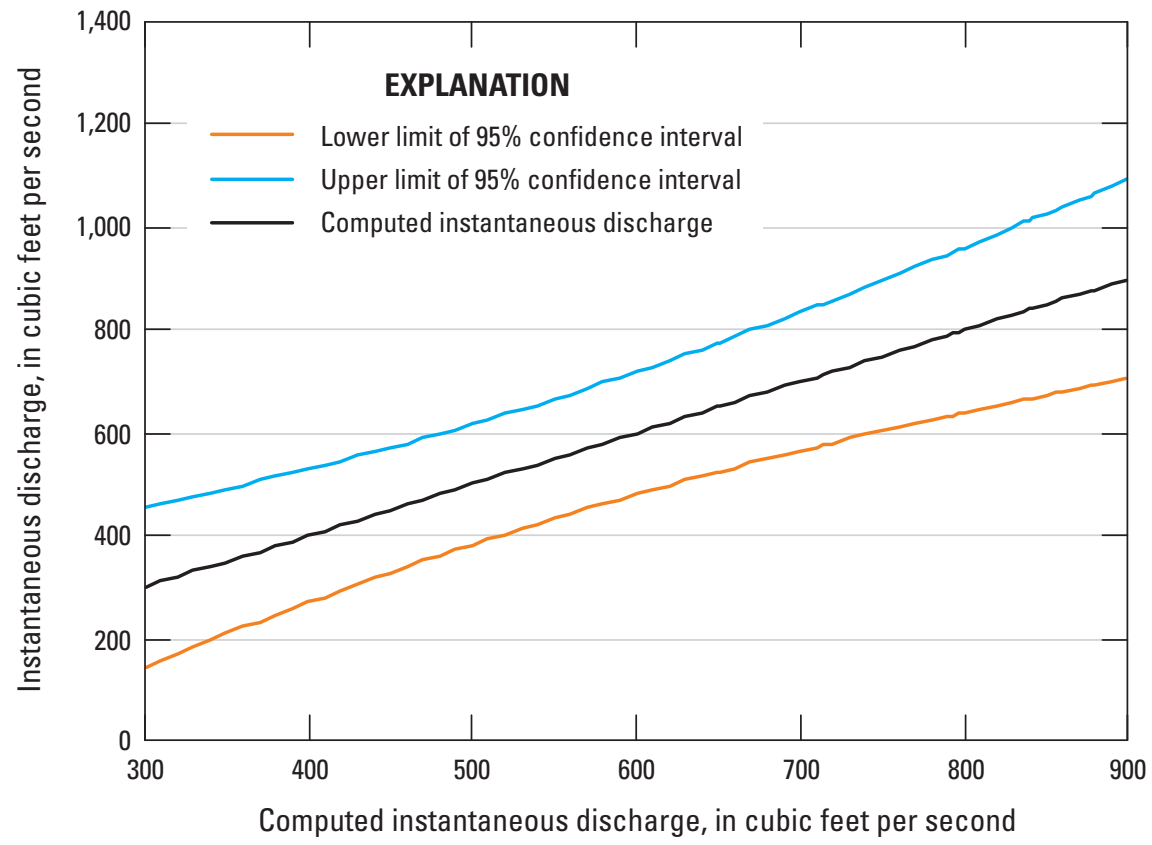

Figure 9. Approximate 95-percent confidence interval of instantaneous discharge uncertainty at USGS streamgage station 03337100 (Boneyard Creek at Lincoln Avenue, Urbana, III.), using measurements obtained from June 2003 through September 2009 when the depth of flow was greater than 5 feet. Assumed measurement error is 5 percent. Measurements included in the rating-curve regression range from 378 to 704 cubic feet per second. 
Table 8. Observed peak discharges and their 95-percent confidence intervals, assuming a measurement error of 5 percent, at USGS streamgage 03337100 (Boneyard Creek at Lincoln Avenue, Urbana, III.) for storm events analyzed during this study.

$\left[Q\right.$, observed peak discharge; $S_{Q}$, discharge uncertainty expressed as a standard deviation; $\mathrm{ft} / \mathrm{s}$, cubic feet per second; $\%$, percent]

\begin{tabular}{|c|c|c|c|c|}
\hline $\begin{array}{c}\text { Date of event } \\
\text { (month/day/year) }\end{array}$ & $\begin{array}{c}\text { Observed peak } \\
\text { discharge, } \boldsymbol{Q} \\
\left(\mathrm{ft}^{3} / \mathrm{s}\right)\end{array}$ & $\begin{array}{c}2 S_{a} \\
\left(\mathrm{ft}^{3} / \mathrm{s}\right)\end{array}$ & $\begin{array}{c}\text { Upper limit of } \\
95 \% \text { confidence } \\
\text { interval, } 0+2 S_{a} \\
\left(\mathrm{ft}^{3} / \mathrm{s}\right)\end{array}$ & $\begin{array}{c}\text { Lower limit of } \\
95 \% \text { confidence } \\
\text { interval, } Q-2 S_{a} \\
\left(\mathrm{ft}^{3} / \mathrm{s}\right)\end{array}$ \\
\hline \multicolumn{5}{|c|}{ Official peak discharges ${ }^{a}$} \\
\hline $7 / 9 / 2003$ & 797 & 160 & 957 & 637 \\
\hline $6 / 26 / 2007$ & 714 & 138 & 852 & 576 \\
\hline $6 / 3 / 2008$ & 837 & 172 & 1,009 & 665 \\
\hline $7 / 8 / 2008$ & 793 & 159 & 952 & 634 \\
\hline $9 / 14 / 2008$ & 877 & 186 & 1,063 & 691 \\
\hline Average of all five events & 804 & 163 & & \\
\hline Average of last four events & 805 & 164 & & \\
\hline \multicolumn{5}{|c|}{ Peak discharges computed with stage-discharge rating 4 , no shifts } \\
\hline $7 / 9 / 2003$ & 856 & 179 & 1,035 & 677 \\
\hline $6 / 26 / 2007$ & 652 & 125 & 777 & 527 \\
\hline $6 / 3 / 2008$ & 842 & 174 & 1,016 & 668 \\
\hline $7 / 8 / 2008$ & 793 & 159 & 952 & 634 \\
\hline 9/14/2008 & 878 & 186 & 1,064 & 692 \\
\hline Average of all five events & 804 & 165 & & \\
\hline Average of last four events & 791 & 161 & & \\
\hline
\end{tabular}

${ }^{a}$ The official peak discharge is defined as the published annual maximum peak discharge, or the value that would have been published as the annual maximum peak, if it had been the largest that water year. 


\section{Comparison of Simulated and Observed Peak Discharges and Stages}

The observed peak discharges at the primary comparison streamgage at Lincoln Avenue and their uncertainties can now be compared with the simulated peak discharges obtained from the four SWMM simulation scenarios. Supplementary comparisons of peak stage at Lincoln Avenue, stage and discharge at the Campus streamgage, and stage at Race Street also are presented.

\section{Discharge at Lincoln Avenue}

The peak discharges obtained from the as-built SWMM4.4H design model at Lincoln Avenue for the four simulation scenarios, along with the observed peak discharges and measures of the simulation error, are given in table 9. The simulated peak discharges with spatially variable precipitation for the first event are quite high as a result of numerical instability in the EXTRAN part of the SWMM model and should be ignored. Several alternative values of the EXTRAN parameters controlling the chosen numerical algorithm were tried, but none were successful in removing this instability. For spatially uniform precipitation, however, it was possible to successfully simulate this event. Overall, a comparison of the simulated peak discharges obtained by using spatially uniform precipitation to those obtained by using spatially variable precipitation show no discernible pattern and have similar averages. The effect of using REGEN $=0.001$ as compared to the REGEN $=0.01$ to create the antecedent soil moisture conditions for the event generating the peak is more consistent: the peak obtained using REGEN $=0.001$, and therefore higher antecedent soil moisture, is always higher compared to $\operatorname{REGEN}=0.01$. The value of REGEN is also important to the comparison of simulated to observed peak discharges: for REGEN $=0.001$ and spatially uniform precipitation, three of five simulated peaks exceed the observed peak and the average error is positive; for REGEN $=0.01$, three of five simulated peaks are less than the observed and the average error is negative.

The numerical values of the observed peak discharges and their 95-percent confidence intervals are given in tables 8 and 10, respectively. The observed and the simulated peak discharges based on SDR 4 are plotted together in figure 10.
When comparing the simulated and observed peak discharges, one must be mindful that modeling uncertainties may not be completely accounted for in the approach taken in this study. These uncertainties include precipitation measurement errors (both at-gage and the spatial variability of the precipitation) and the antecedent moisture condition of the soil. Figure 10 shows that all of the simulated peak discharge values lie within or very near the 95-percent confidence intervals of the observed peak discharges. For one event, on July 9, 2003, simulated discharges are near the upper limit of the 95-percent confidence interval of the observed value; for one other event, on June 3, 2008, the simulations are near the lower limit of the 95 -percent confidence interval of the observed value. For two events, on June 26, 2007, and July 8, 2008, simulated values are distributed around the center of the of the 95-percent confidence intervals of the observed value, though the simulated discharges for June 26, 2007, are lower and those for July 8, 2008, are higher. For the remaining event, on September 14,2008 , the simulations are in the upper half of the 95-percent confidence interval of the observed value. Therefore, it appears that, overall, the model is simulating the peak discharges at Lincoln Avenue usually within the 95-percent confidence intervals and with differences that are approximately balanced between overprediction and underprediction.

The overall bias of the simulated peak discharges is quantified in table 10 . The results for spatially uniform precipitation, for which all five events could be simulated, show a positive average bias of $63 \mathrm{ft}^{3} / \mathrm{s}$ of the simulations compared to either the official or SDR 4-derived observations where $\mathrm{REGEN}=0.001$ (therefore, somewhat wetter antecedent moisture conditions) and a small positive bias of 1-2 $\mathrm{ft}^{3} / \mathrm{s}$ where $\mathrm{REGEN}=0.01$ (the default and design model value). When considering just the last four events that could be simulated for spatially variable precipitation, the bias remains positive for REGEN $=0.001$ in the case of the SDR 4-based observed values but becomes negative for REGEN $=0.01$. This change is not surprising because the July 9, 2003, event has the largest positive simulation bias among all the events. Considering all the events, however, the average simulation bias is small to significantly positive. Combining the uncertainty and bias results, the five events studied here provide no clear evidence that the Boneyard Creek SWMM design model peak discharges at Lincoln Avenue are significantly inaccurate or biased. 
Table 9. Comparison of simulated and observed peak discharges at USGS streamgage 03337100 (Boneyard Creek at Lincoln Avenue, Urbana, III.) for storm events analyzed during this study.

[ft $/ \mathrm{s}$, cubic feet per second; REGEN, Stormwater Management Model (SWMM) parameter controlling rate at which infiltration capacity is regenerated during inter-storm periods; N/A, not applicable

\begin{tabular}{|c|c|c|c|c|c|c|c|c|c|}
\hline \multirow{4}{*}{$\begin{array}{c}\text { Event date } \\
\text { (month/day/year) }\end{array}$} & \multirow{4}{*}{$\begin{array}{l}\text { Observed peak } \\
\text { discharge (stage- } \\
\text { discharge rating 4, } \\
\text { no shifts) } \\
\left(\mathrm{ft}^{3} / \mathrm{s}\right)\end{array}$} & \multicolumn{8}{|c|}{ Simulated peak discharge } \\
\hline & & \multicolumn{4}{|c|}{ Spatially uniform precipitation } & \multicolumn{4}{|c|}{ Spatially variable precipitation } \\
\hline & & \multicolumn{2}{|c|}{ REGEN = 0.01} & \multicolumn{2}{|c|}{ REGEN = 0.001} & \multicolumn{2}{|c|}{ REGEN = 0.01} & \multicolumn{2}{|c|}{ REGEN = 0.001} \\
\hline & & $\begin{array}{c}\text { Discharge } \\
\left(\mathrm{ft}^{3} / \mathrm{s}\right)\end{array}$ & $\begin{array}{l}\text { Percent } \\
\text { error }^{\mathrm{a}}\end{array}$ & $\begin{array}{c}\text { Discharge } \\
\qquad\left(\mathrm{ft}^{3} / \mathrm{s}\right)\end{array}$ & $\begin{array}{l}\text { Percent } \\
\text { error }^{\mathrm{a}}\end{array}$ & $\begin{array}{c}\text { Discharge } \\
\left(\mathrm{ft}^{3} / \mathrm{s}\right)\end{array}$ & $\begin{array}{c}\text { Percent } \\
\text { error }^{\mathrm{a}}\end{array}$ & $\begin{array}{c}\text { Discharge } \\
\left(\mathrm{ft}^{3} / \mathrm{s}\right)\end{array}$ & $\begin{array}{c}\text { Percent } \\
\text { error }^{\mathrm{a}}\end{array}$ \\
\hline $7 / 9 / 2003$ & 856 & 1,024 & 19.6 & 1,049 & 22.5 & $1,431^{\mathrm{b}}$ & N/A & $1,514^{\mathrm{b}}$ & $\mathrm{N} / \mathrm{A}$ \\
\hline $6 / 26 / 2007$ & 652 & 531 & -18.6 & 616 & -5.5 & 633 & -2.9 & 700 & 7.4 \\
\hline $6 / 3 / 2008$ & 842 & 701 & -16.7 & 722 & -14.3 & 703 & -16.5 & 721 & -14.4 \\
\hline $7 / 8 / 2008$ & 793 & 746 & -5.9 & 917 & 15.6 & 716 & -9.7 & 786 & -0.9 \\
\hline $9 / 14 / 2008$ & 877 & 1,001 & 14.1 & 1,055 & 20.3 & 943 & 7.5 & 1,000 & 14.0 \\
\hline $\begin{array}{l}\text { Average of all five } \\
\text { events }\end{array}$ & 804 & 801 & -1.49 & 872 & 7.74 & $\mathrm{~N} / \mathrm{A}$ & N/A & N/A & N/A \\
\hline $\begin{array}{l}\text { Average of last four } \\
\text { events }\end{array}$ & 791 & 745 & -6.8 & 828 & 4.0 & 749 & -5.4 & 802 & 1.5 \\
\hline
\end{tabular}

aPercent error is defined as $100 \times\left(Q_{\text {sim }}-Q_{o b s}\right) / Q_{o b s}$, where $Q_{\text {sim }}$ is the simulated peak discharge and $Q_{o b s}$ is the observed peak discharge.

'Peak-discharge value occurs during period of significant model instability. 
Table 10. Simulated peak discharges and differences between simulated and observed peak discharges at USGS streamgage 03337100 (Boneyard Creek at Lincoln Avenue, Urbana, III.) for storm events analyzed during this study.

[REGEN, Stormwater Management Model (SWMM) RUNOFF module parameter controlling the rate at which soil infiltration capacity is regenerated between storm events; $Q_{\text {sim }}$, simulated peak discharge; $Q_{o b s-o f f}$ official observed peak discharge; $Q_{o b s-r 4}$, observed peak discharge computed with stage-discharge rating 4 and no shifts; $\mathrm{ft}^{3} / \mathrm{s}$, cubic feet per second; N/A, not available]

\begin{tabular}{|c|c|c|c|c|c|c|}
\hline \multirow{2}{*}{$\begin{array}{c}\text { Date of event } \\
\text { (month/day/year) }\end{array}$} & \multicolumn{3}{|c|}{ REGEN $=0.001$} & \multicolumn{3}{|c|}{ REGEN = 0.01} \\
\hline & $\underset{\left(\mathrm{ft}^{\mathrm{t}} / \mathrm{s}\right)}{\boldsymbol{O}_{\mathrm{sim}}}$ & $\begin{array}{l}\boldsymbol{Q}_{\text {sim }}-\boldsymbol{Q}_{\text {obs-offf }} \\
\quad\left(\mathrm{ft}^{3} / \mathbf{s}\right)\end{array}$ & $\begin{array}{c}\boldsymbol{Q}_{\text {sim }}-\boldsymbol{Q}_{\text {obs-r4 }} \\
\left(\mathbf{f t t}^{3} / \mathbf{s}\right)\end{array}$ & $\begin{array}{c}\boldsymbol{O}_{\text {sim }} \\
\left(\mathrm{ft}^{\mathrm{t}} / \mathbf{s}\right)\end{array}$ & $\begin{array}{c}\boldsymbol{Q}_{\text {sim }}-\boldsymbol{Q}_{\text {obs-off }} \\
\left(\mathbf{f t}^{3} / \mathbf{s}\right)\end{array}$ & $\begin{array}{l}\mathbf{O}_{\text {sim }}-\mathbf{O}_{\text {obs }-4} \\
\quad\left(\mathrm{ft}^{3} / \mathbf{s}\right)\end{array}$ \\
\hline \multicolumn{7}{|c|}{ Spatially uniform precipitation } \\
\hline $7 / 9 / 2003$ & 1,024 & 227 & 168 & 1,049 & 252 & 193 \\
\hline $6 / 26 / 2007$ & 616 & -98 & -36 & 531 & -183 & -121 \\
\hline $6 / 3 / 2008$ & 722 & -115 & -120 & 701 & -136 & -141 \\
\hline $7 / 8 / 2008$ & 917 & 124 & 124 & 746 & -47 & -47 \\
\hline $9 / 14 / 2008$ & 1,055 & 178 & 177 & 1,001 & 124 & 123 \\
\hline Average of all 5 events & 867 & 63.2 & 62.6 & 806 & 2.0 & 1.4 \\
\hline Average of last 4 events & 828 & 22.3 & 36.3 & 745 & -60.5 & -46.5 \\
\hline \multicolumn{7}{|c|}{ Spatially variable precipitation } \\
\hline 7/9/2003 & N/A & N/A & N/A & N/A & N/A & N/A \\
\hline $6 / 26 / 2007$ & 700 & -14 & 48 & 633 & -81 & -19 \\
\hline $6 / 3 / 2008$ & 721 & -116 & -121 & 703 & -134 & -139 \\
\hline $7 / 8 / 2008$ & 786 & -7 & -7 & 716 & -77 & -77 \\
\hline $9 / 14 / 2008$ & 1,000 & 123 & 122 & 943 & 66 & 65 \\
\hline Average of all 5 events & N/A & N/A & N/A & N/A & N/A & N/A \\
\hline Average of last 4 events & 802 & -3.5 & 10.5 & 749 & -56.5 & -42.5 \\
\hline
\end{tabular}




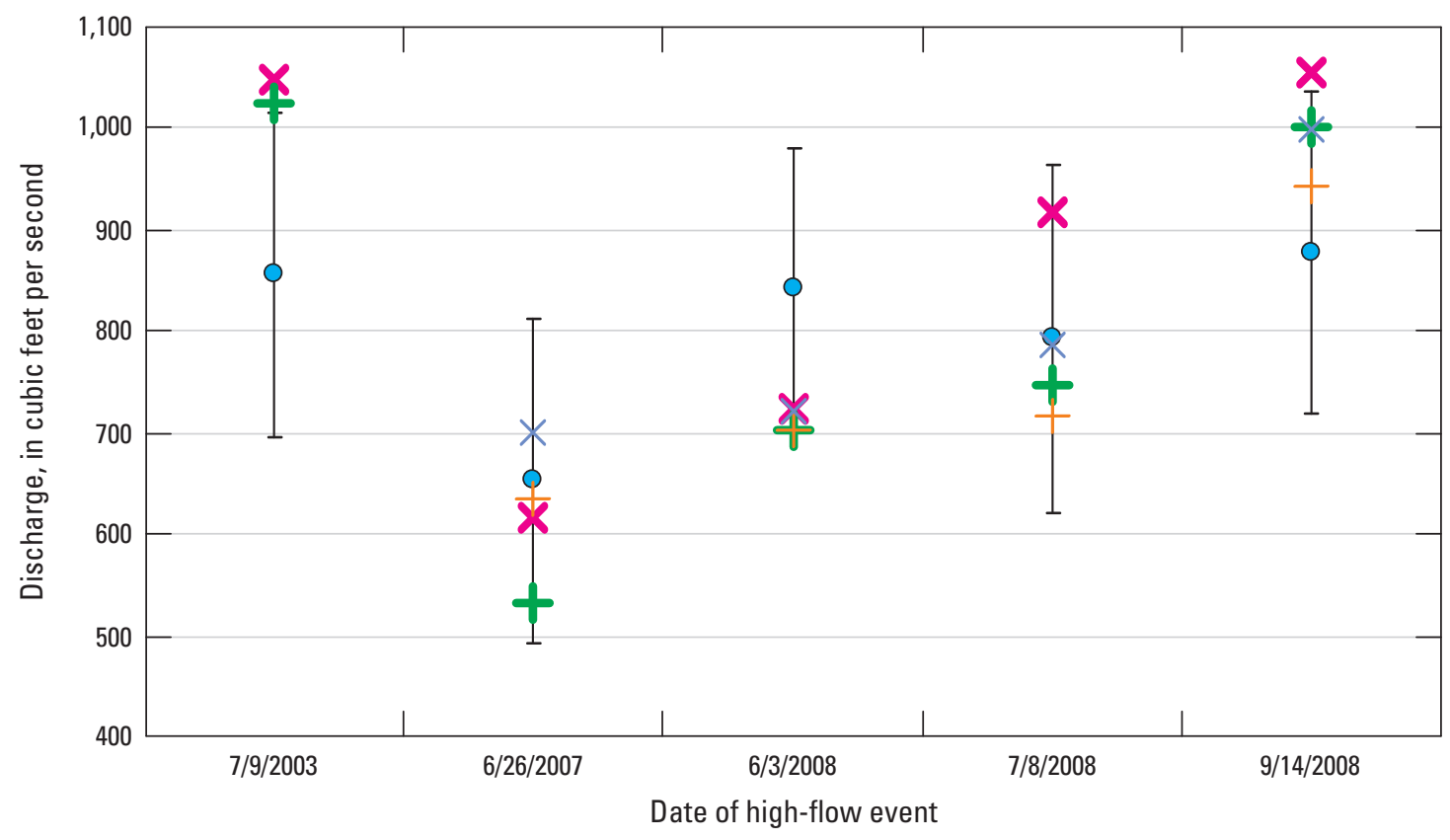

\section{EXPLANATION}

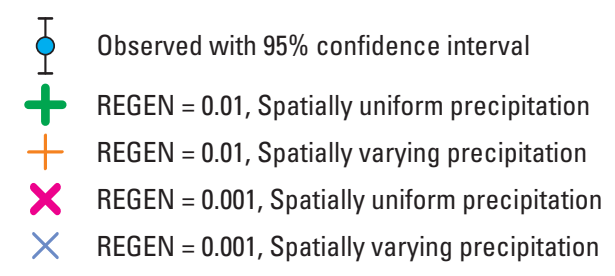

Figure 10. Peak discharges from SWMM4 simulations and observed values with estimated 95-percent confidence intervals for USGS streamgage 03337100 (Boneyard Creek at Lincoln Avenue, Urbana, III.), for storm events analyzed during this study. Observed discharges were computed from stage-discharge rating 4, with no shifts. For the event on July 9, 2003, only discharge values resulting from stable simulations are shown. 


\section{Stage at Lincoln Avenue and Stage and Discharge at Supplementary Streamgages}

Not surprisingly, but reassuringly, the pattern of peak stages from the four SWMM simulation scenarios relative to the observed peak stage at Lincoln Avenue (fig. 11) is similar to the peak-discharge comparison at the same location (fig. 10), though quantitatively, the errors are shifted in the positive direction (table 11); that is, the simulated peak stages are usually somewhat higher than the observed. This correspondence between peak discharge and stage comparisons is reassuring because it indicates approximate agreement in the observed and modeled stage-discharge relations, at least for peak values.

At the Campus streamgage, simulated peak discharge (fig. 12 and table 12) and stage (fig. 13 and table 13) both tend to be low compared to the observations; like at Lincoln Avenue, however, the stage differences (simulated minus observed) are more positive than the discharge differences. The reason for the apparent negative bias in the simulated peaks at the Campus streamgage is not immediately clear. One possibility is that although both the Lincoln Avenue and Campus streamgages are recently constructed, the rating curve for Lincoln Avenue is based on many more high-flow measurements than that for the Campus streamgage because of the emphasis on measurements at Lincoln Avenue as a result of this study.
Only stage comparisons are available at the Race Street streamgage. The distribution pattern of the simulated stages around the observations is similar to that at the other gages (fig. 14 and table 14). Here, like at Lincoln Avenue (table 11 and fig. 11) but unlike at the Campus streamgage (figs. 12 and 13), the simulated stages tend to be somewhat high relative to the observed stages, though not by as much as at Lincoln Avenue.

The common pattern of distribution of simulated values relative to the observations across the different streamgages (the July 9, 2003, simulated peak stages and discharges being generally high relative to the observations, the June 26, 2007, and June 3, 2008, simulations being low, and the September 14, 2008, simulations being again high) bears further comment. This pattern could have resulted from either a hydrologic cause (errors in the precipitation measurements or antecedent moisture values in the model) or a hydraulic cause (errors in the SWMM model results for the particular flows in the Boneyard pipe and channel system for that event). Observed-flow computation error seems unlikely to explain this common pattern because the pattern is seen across three different streamgages. The tendency for simulations at the different gages to be generally higher or lower relative to observations at other gages could, however, result at least partly from errors in observed-flow computation (for example, uncertainty in the rating curves in the case of peak discharges), in addition to SWMM model error. 


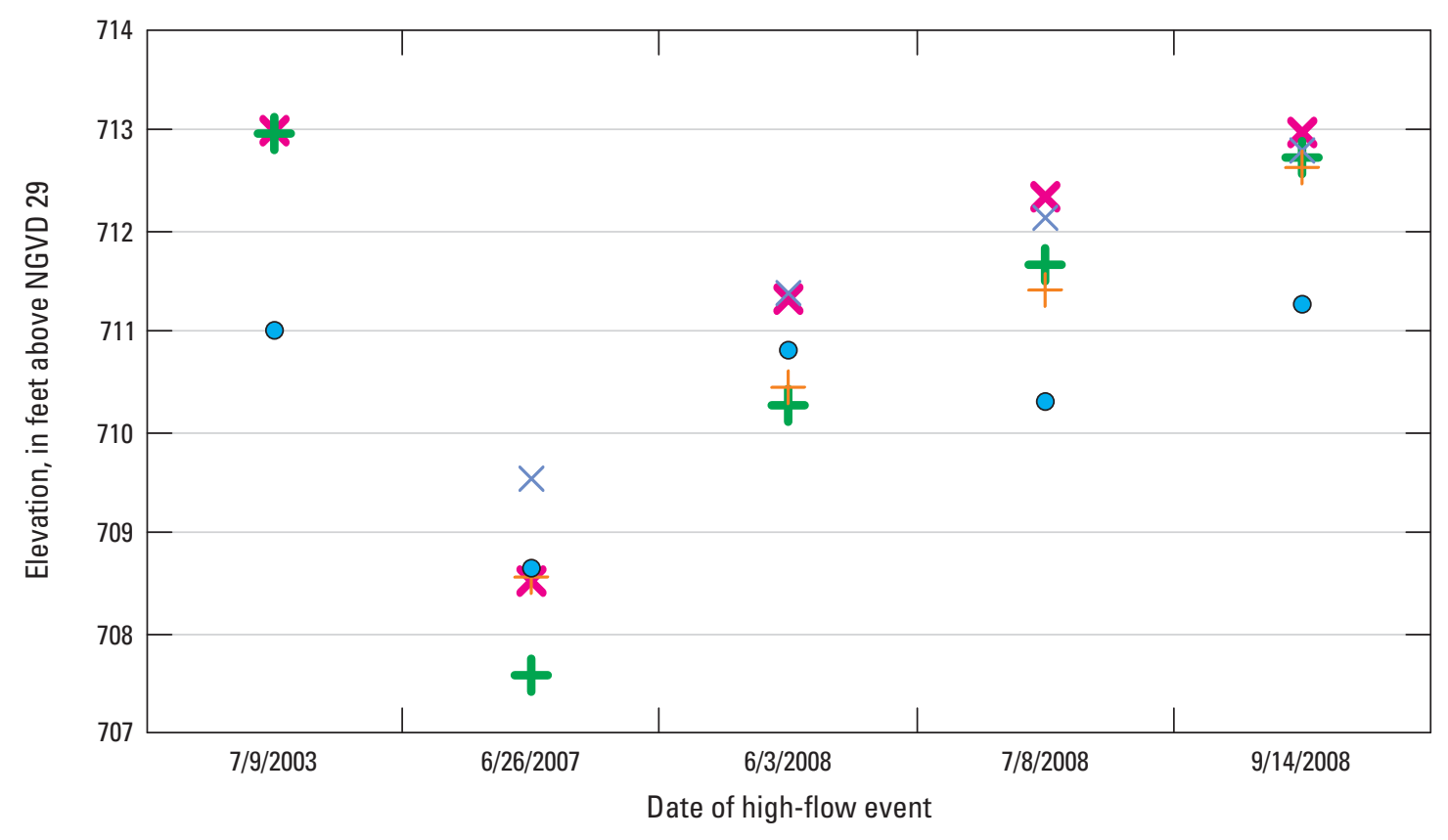

\section{EXPLANATION}

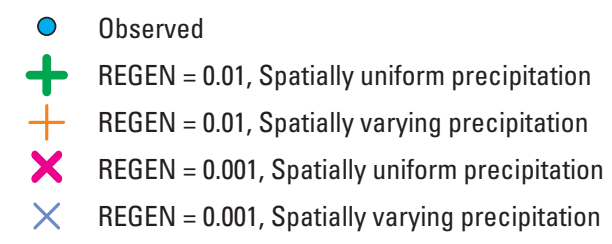

Figure 11. Peak stages from SWMM4 simulations and observed values at USGS streamgage 03337100 (Boneyard Creek at Lincoln Avenue, Urbana, Ill.) for storm events analyzed during this study. For the July 9, 2003, event, only values resulting from stable simulations are shown. 
Table 11. Comparison of simulated and observed peak stages at USGS streamgage 03337100 (Boneyard Creek at Lincoln Avenue, Urbana, III.) for storm events analyzed during this study.

[ft, feet; NGVD 29, National Geodetic Vertical Datum of 1929; REGEN, Stormwater Management Model (SWMM) parameter controlling rate at which infiltration capacity is regenerated during inter-storm periods; N/A, not applicable]

\begin{tabular}{|c|c|c|c|c|c|c|c|c|c|c|}
\hline \multirow{4}{*}{$\begin{array}{c}\text { Event date } \\
\text { (month/day/year) }\end{array}$} & \multicolumn{2}{|c|}{ Observed peak stage } & \multicolumn{8}{|c|}{ Simulated peak stage (ft, NGVD 29) } \\
\hline & \multirow{3}{*}{$\begin{array}{c}\text { Gage height } \\
\text { (ft) }\end{array}$} & \multirow{3}{*}{$\begin{array}{l}\text { Elevation } \\
\text { (datum: } \\
694.00 \mathrm{ft} \text {, } \\
\text { NGVD 29) }\end{array}$} & \multicolumn{4}{|c|}{ Spatially uniform precipitation } & \multicolumn{4}{|c|}{ Spatially variable precipitation } \\
\hline & & & \multicolumn{2}{|c|}{ REGEN = 0.01} & \multicolumn{2}{|c|}{ REGEN = 0.001} & \multicolumn{2}{|c|}{ REGEN = 0.01} & \multicolumn{2}{|c|}{ REGEN = 0.001} \\
\hline & & & $\begin{array}{c}\text { Elevation } \\
\text { (ft) }\end{array}$ & $\begin{array}{c}\text { Error } \\
\text { (ft) }\end{array}$ & $\begin{array}{c}\text { Elevation } \\
\text { (ft) }\end{array}$ & $\begin{array}{c}\text { Error } \\
\text { (ft) }\end{array}$ & $\begin{array}{l}\text { Elevation } \\
\text { (ft) }\end{array}$ & $\begin{array}{c}\text { Error } \\
\text { (ft) }\end{array}$ & $\begin{array}{c}\text { Elevation } \\
\text { (ft) }\end{array}$ & $\begin{array}{c}\text { Error } \\
\text { (ft) }\end{array}$ \\
\hline $7 / 9 / 2003$ & 17.00 & 711.00 & 712.96 & 1.96 & 712.99 & 1.99 & $713.85^{\mathrm{a}}$ & N/A & $713.89^{a}$ & N/A \\
\hline $6 / 26 / 2007$ & 14.63 & 708.63 & 707.56 & -1.07 & 708.50 & -0.13 & 708.54 & -0.09 & 709.52 & 0.89 \\
\hline $6 / 3 / 2008$ & 16.80 & 710.80 & 710.25 & -0.55 & 711.31 & 0.51 & 710.43 & -0.37 & 711.37 & 0.57 \\
\hline $7 / 8 / 2008$ & 16.29 & 710.29 & 711.65 & 1.36 & 712.33 & 2.04 & 711.40 & 1.11 & 712.12 & 1.83 \\
\hline $9 / 14 / 2008$ & 17.26 & 711.26 & 712.72 & 1.46 & 712.97 & 1.71 & 712.62 & 1.36 & 712.79 & 1.53 \\
\hline $\begin{array}{l}\text { Average of all five } \\
\text { events }\end{array}$ & 16.40 & 710.40 & 711.03 & 0.63 & 711.62 & 1.22 & $\mathrm{~N} / \mathrm{A}$ & N/A & N/A & N/A \\
\hline $\begin{array}{l}\text { Average of last four } \\
\text { events }\end{array}$ & 16.25 & 710.25 & 710.55 & 0.30 & 711.28 & 1.03 & 710.75 & 0.50 & 711.45 & 1.21 \\
\hline
\end{tabular}

aPeak-stage value occurs during period of significant model instability. 


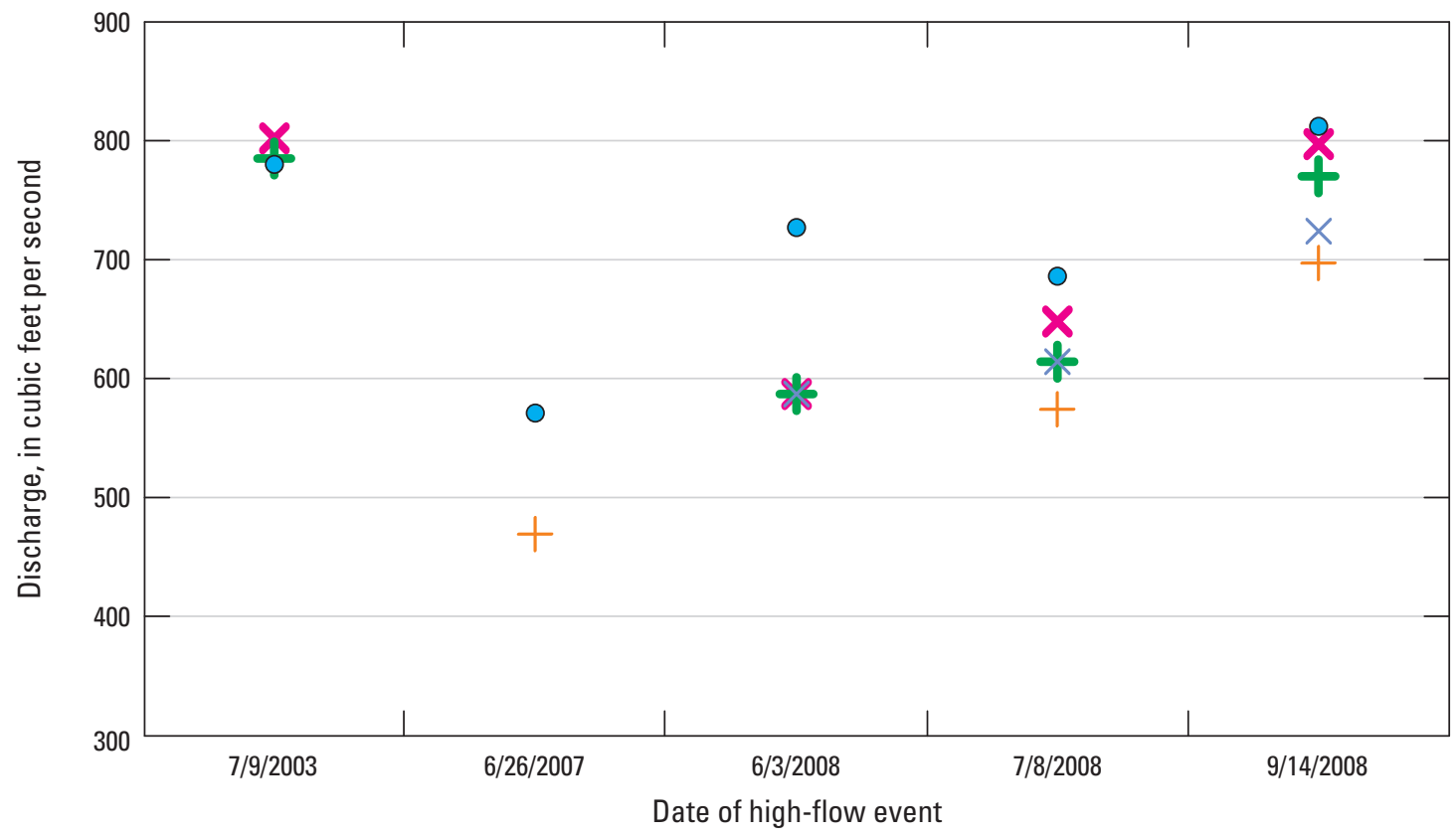

\section{EXPLANATION}

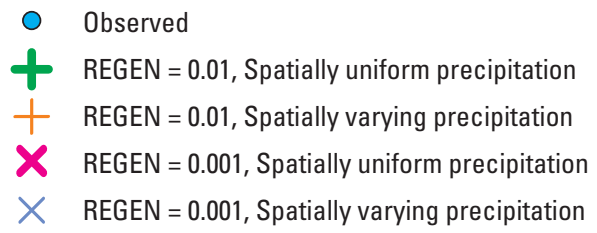

Figure 12. Peak discharges from SWMM4 simulations and observed values at USGS streamgage 03337000 (Boneyard Creek at Urbana, III.) on the campus of the University of Illinois at Urbana-Champaign for storm events analyzed during this study. For the July 9, 2003, June 26, 2007, and June 3, 2008 events, only values resulting from stable simulations are shown. 
Table 12. Comparison of simulated and observed peak discharges at USGS streamgage 03337000 (Boneyard Creek at Urbana, III.) on the campus of the University of Illinois at Urbana-Champaign for storm events analyzed during this study.

$\left[\mathrm{ft}^{3} / \mathrm{s}\right.$, cubic feet per second; REGEN, Stormwater Management Model (SWMM) parameter controlling rate at which infiltration capacity is regenerated during inter-storm periods; N/A, not applicable]

\begin{tabular}{|c|c|c|c|c|c|c|c|c|c|}
\hline \multirow{4}{*}{$\begin{array}{c}\text { Event date } \\
\text { (month/day/year) }\end{array}$} & \multirow{4}{*}{$\begin{array}{l}\text { Observed peak } \\
\text { discharge } \\
\text { (stage-discharge } \\
\text { rating 20, } \\
\text { no shifts) } \\
\left(\mathrm{ft}^{3} / \mathrm{s}\right)\end{array}$} & \multicolumn{8}{|c|}{ Simulated peak discharge } \\
\hline & & \multicolumn{4}{|c|}{ Spatially uniform precipitation } & \multicolumn{4}{|c|}{ Spatially variable precipitation } \\
\hline & & \multicolumn{2}{|c|}{ REGEN = 0.01} & \multicolumn{2}{|c|}{ REGEN = 0.001} & \multicolumn{2}{|c|}{ REGEN = 0.01} & \multicolumn{2}{|c|}{ REGEN = 0.001} \\
\hline & & $\begin{array}{l}\text { Discharge } \\
\quad\left(\mathrm{ft}^{3} / \mathrm{s}\right)\end{array}$ & $\begin{array}{l}\text { Percent } \\
\text { error }^{\mathrm{a}}\end{array}$ & $\begin{array}{c}\text { Discharge } \\
\left(\mathrm{ft}^{3} / \mathbf{s}\right)\end{array}$ & $\begin{array}{c}\text { Percent } \\
\text { error }^{\mathrm{a}}\end{array}$ & $\begin{array}{c}\text { Discharge } \\
\left(\mathrm{ft}^{3} / \mathrm{s}\right)\end{array}$ & $\begin{array}{c}\text { Percent } \\
\text { error }^{\mathrm{a}}\end{array}$ & $\begin{array}{c}\text { Discharge } \\
\left(\mathrm{ft}^{3} / \mathbf{s}\right)\end{array}$ & $\begin{array}{c}\text { Percent } \\
\text { error }^{\mathrm{a}}\end{array}$ \\
\hline $7 / 9 / 2003$ & 780 & 785 & 0.6 & 802 & 2.8 & $853^{b}$ & N/A & $858^{\mathrm{b}}$ & N/A \\
\hline $6 / 26 / 2007$ & 571 & $455^{\mathrm{b}}$ & N/A & $595^{\mathrm{b}}$ & N/A & 469 & -17.9 & $516^{\mathrm{b}}$ & N/A \\
\hline $6 / 3 / 2008$ & 727 & 588 & -19.1 & 587 & -19.3 & $566^{\mathrm{b}}$ & N/A & 587 & -19.3 \\
\hline $7 / 8 / 2008$ & 686 & 615 & -10.3 & 648 & -5.5 & 574 & -16.3 & 614 & -10.5 \\
\hline $9 / 14 / 2008$ & 812 & 770 & -5.2 & 797 & -1.8 & 697 & -14.2 & 724 & -10.8 \\
\hline $\begin{array}{l}\text { Average of all five } \\
\text { events }\end{array}$ & 715 & 690 & -8.50 & 709 & -6.0 & N/A & N/A & N/A & N/A \\
\hline $\begin{array}{l}\text { Average of last four } \\
\text { events }\end{array}$ & 699 & 658 & -11.5 & 677 & -8.9 & 580 & -16.1 & 642 & -13.5 \\
\hline
\end{tabular}

aPercent error is defined as $100 \times\left(Q_{\text {sim }}-Q_{\text {obs }}\right) / Q_{\text {obs }}$, where $Q_{\text {sim }}$ is the simulated
'Peak-discharge value occurs during period of significant model instability. 


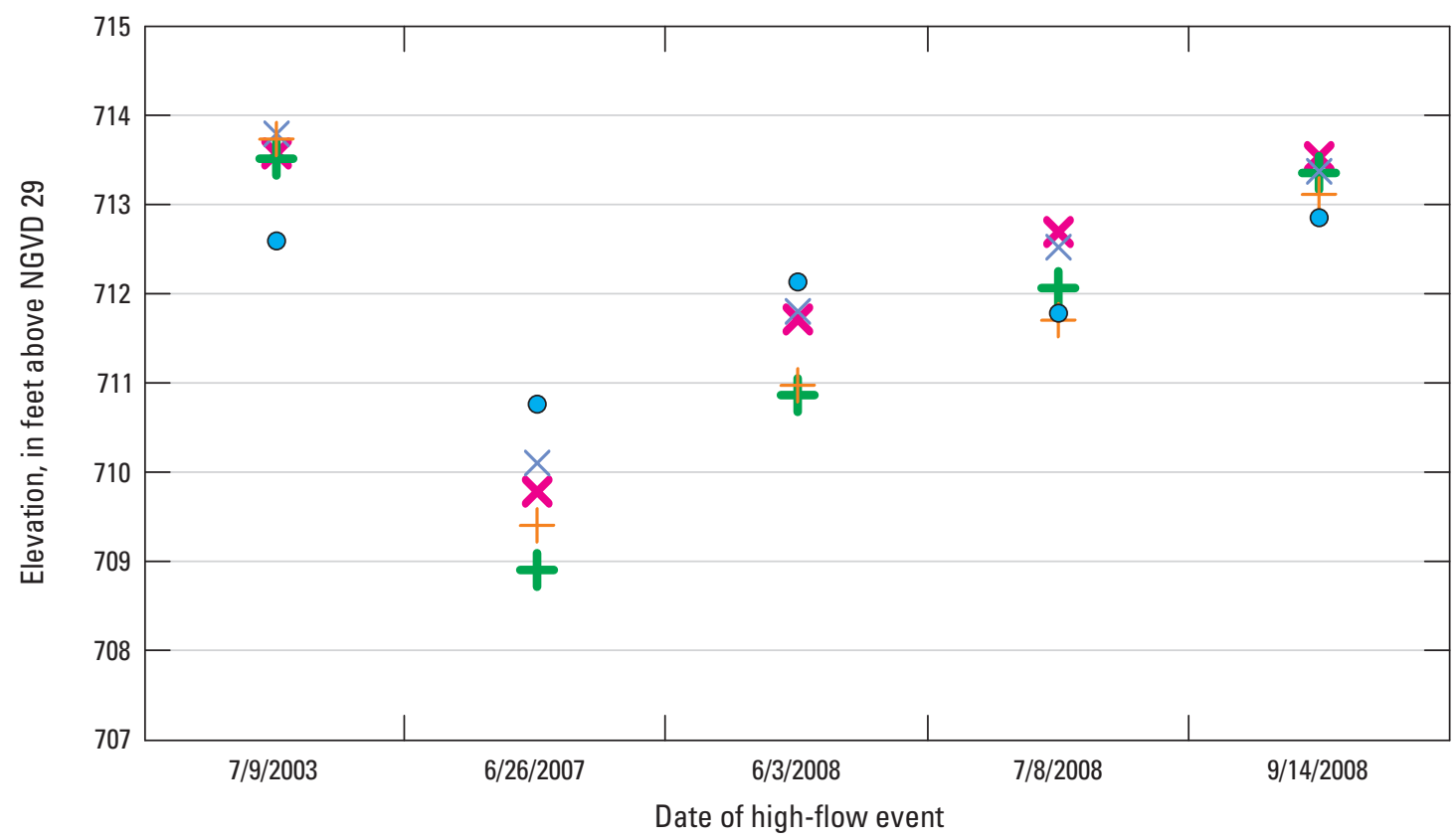

\section{EXPLANATION}

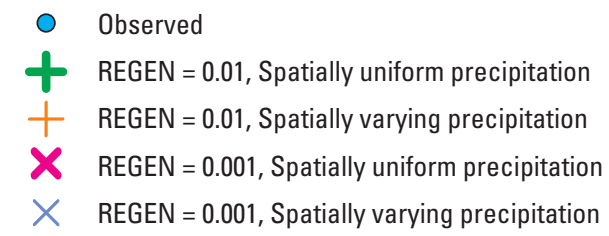

Figure 13. Peak stages from SWMM4 simulations and observed values at USGS gaging station 03337000 (Boneyard Creek at Urbana, III.) on the campus of the University of Illinois at Urbana-Champaign, for storm events analyzed for this study. 
Table 13. Comparison of simulated and observed peak stages at USGS streamgage 03337000 (Boneyard Creek at Urbana, III.) on the campus of the University of Illinois at Urbana-Champaign for storm events analyzed during this study.

[ft, feet; NGVD 29, National Geodetic Vertical Datum of 1929; REGEN, Stormwater Management Model (SWMM) parameter controlling rate at which infiltration capacity is regenerated during inter-storm periods; N/A, not applicable]

\begin{tabular}{|c|c|c|c|c|c|c|c|c|c|c|}
\hline \multirow{4}{*}{$\begin{array}{c}\text { Event date } \\
\text { (month/day/year) }\end{array}$} & \multicolumn{2}{|c|}{ Observed peak stage } & \multicolumn{8}{|c|}{ Simulated peak stage (ft, NGVD 29) } \\
\hline & \multirow{3}{*}{$\begin{array}{c}\text { Gage height } \\
\text { (ft) }\end{array}$} & \multirow{3}{*}{$\begin{array}{l}\text { Elevation } \\
\text { (datum: } \\
694.00 \mathrm{ft} \text {, } \\
\text { NGVD 29) }\end{array}$} & \multicolumn{4}{|c|}{ Spatially uniform precipitation } & \multicolumn{4}{|c|}{ Spatially variable precipitation } \\
\hline & & & \multicolumn{2}{|c|}{ REGEN = 0.01} & \multicolumn{2}{|c|}{ REGEN = 0.001} & \multicolumn{2}{|c|}{ REGEN = 0.01} & \multicolumn{2}{|c|}{ REGEN = 0.001} \\
\hline & & & $\begin{array}{l}\text { Elevation } \\
\quad \text { (ft) }\end{array}$ & $\begin{array}{l}\text { Error } \\
\text { (ft) }\end{array}$ & $\begin{array}{l}\text { Elevation } \\
\quad(\mathrm{ft})\end{array}$ & $\begin{array}{l}\text { Error } \\
\text { (ft) }\end{array}$ & $\begin{array}{l}\text { Elevation } \\
\quad(\mathrm{ft})\end{array}$ & $\begin{array}{l}\text { Error } \\
(\mathrm{ft})\end{array}$ & $\begin{array}{c}\text { Elevation } \\
\quad(\mathrm{ft})\end{array}$ & $\begin{array}{c}\text { Error } \\
\text { (ft) }\end{array}$ \\
\hline $7 / 9 / 2003$ & 18.59 & 712.59 & 713.51 & 0.92 & 713.57 & 0.98 & 713.73 & 1.14 & 713.79 & 1.20 \\
\hline $6 / 26 / 2007$ & 16.76 & 710.76 & 708.90 & -1.86 & 709.78 & -0.98 & 709.40 & -1.36 & 710.10 & -0.66 \\
\hline $6 / 3 / 2008$ & 18.13 & 712.13 & 710.86 & -1.27 & 711.71 & -0.42 & 710.97 & -1.16 & 711.80 & -0.33 \\
\hline $7 / 8 / 2008$ & 17.78 & 711.78 & 712.06 & 0.28 & 712.69 & 0.91 & 711.70 & -0.08 & 712.52 & 0.74 \\
\hline $9 / 14 / 2008$ & 18.85 & 712.85 & 713.35 & 0.50 & 713.53 & 0.68 & 713.11 & 0.26 & 713.37 & 0.52 \\
\hline $\begin{array}{l}\text { Average of all five } \\
\text { events }\end{array}$ & 18.02 & 712.02 & 711.74 & -0.29 & 712.26 & 0.23 & 711.78 & -0.24 & 712.32 & 0.29 \\
\hline $\begin{array}{l}\text { Average of last four } \\
\text { events }\end{array}$ & 17.88 & 711.88 & 711.29 & -0.59 & 711.93 & 0.05 & 711.30 & -0.58 & 711.95 & 0.07 \\
\hline
\end{tabular}




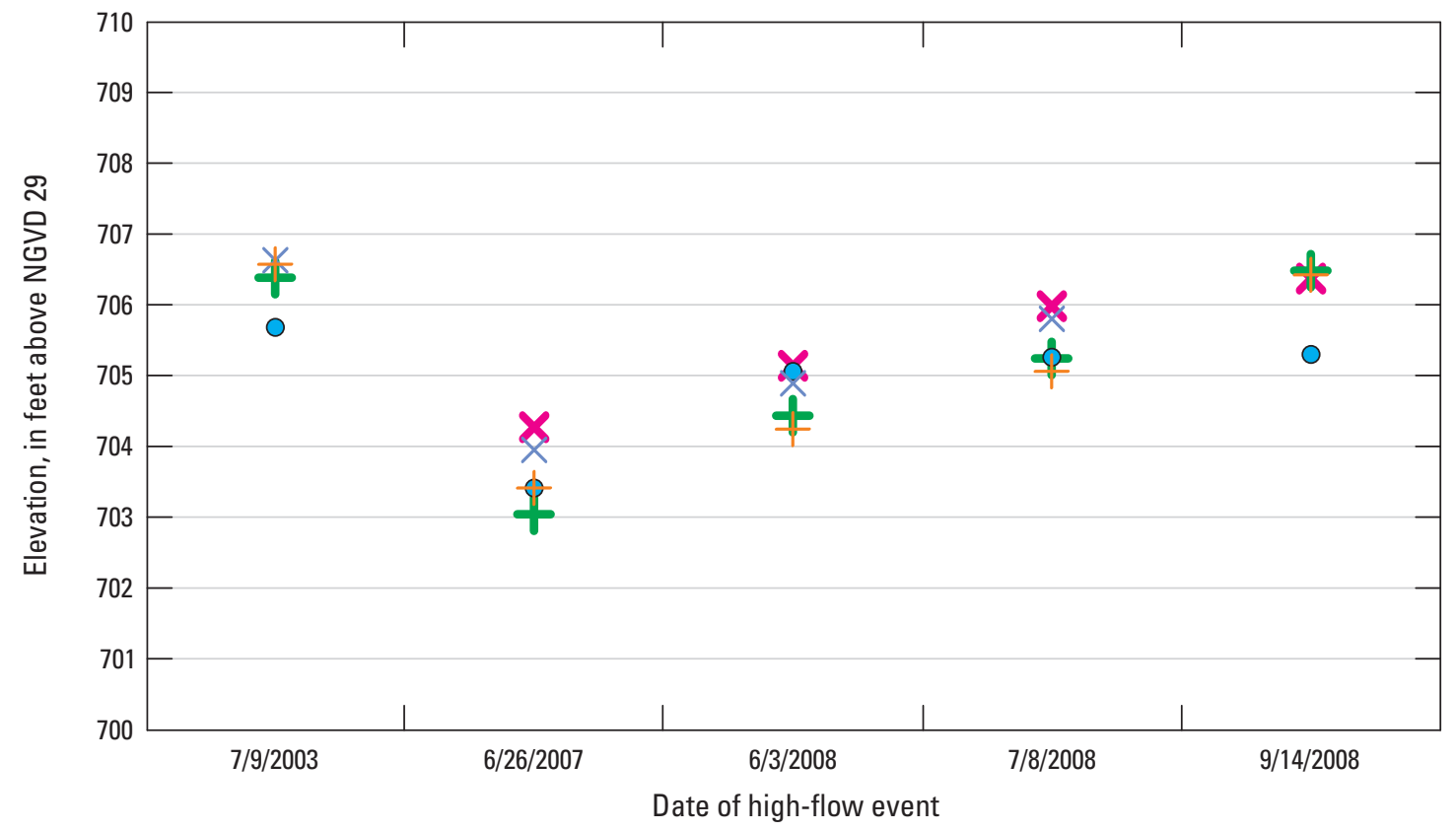

EXPLANATION

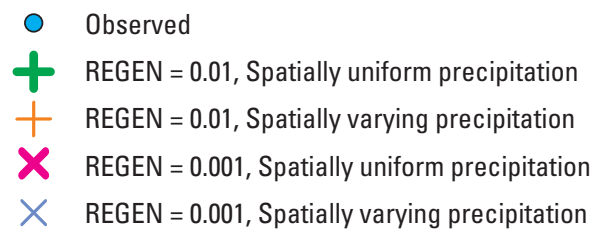

Figure 14. Peak stages from SWMM4 simulations and observed values at USGS streamgage 03337250 (Boneyard Creek at Race Street, Urbana, III.) for storm events analyzed during this study. For the July 9, 2003, and September 14, 2008, events, only values resulting from stable simulations are shown. 
Table 14. Comparison of simulated and observed peak stages at USGS streamgage 03337250 (Boneyard Creek at Race Street, Urbana, III.) for storm events analyzed during this study.

[ft, feet; NGVD 29, National Geodetic Vertical Datum of 1929; REGEN, Stormwater Management Model (SWMM) parameter controlling rate at which infiltration capacity is regenerated during inter-storm periods; N/A, not applicable]

\begin{tabular}{|c|c|c|c|c|c|c|c|c|c|c|}
\hline \multirow{4}{*}{$\begin{array}{c}\text { Event date } \\
\text { (month/day/year) }\end{array}$} & \multicolumn{2}{|c|}{ Observed peak stage } & \multicolumn{8}{|c|}{ Simulated peak stage (ft, NGVD 29) } \\
\hline & \multirow{3}{*}{$\begin{array}{c}\text { Gage height } \\
\text { (ft) }\end{array}$} & \multirow{3}{*}{$\begin{array}{c}\text { Elevation } \\
\text { (datum: } 694.00 \\
\text { ft, NGVD 29) }\end{array}$} & \multicolumn{4}{|c|}{ Spatially uniform precipitation } & \multicolumn{4}{|c|}{ Spatially variable precipitation } \\
\hline & & & \multicolumn{2}{|c|}{ REGEN = 0.01} & \multicolumn{2}{|c|}{ REGEN = 0.001} & \multicolumn{2}{|c|}{ REGEN = 0.01} & \multicolumn{2}{|c|}{ REGEN = 0.001} \\
\hline & & & $\begin{array}{c}\text { Elevation } \\
\text { (ft) }\end{array}$ & $\begin{array}{l}\text { Error } \\
\text { (ft) }\end{array}$ & $\begin{array}{l}\text { Elevation } \\
\quad(\mathrm{ft})\end{array}$ & $\begin{array}{l}\text { Error } \\
\text { (ft) }\end{array}$ & $\begin{array}{l}\text { Elevation } \\
\quad(\mathrm{ft})\end{array}$ & $\begin{array}{c}\text { Error } \\
\text { (ft) }\end{array}$ & $\begin{array}{c}\text { Elevation } \\
\quad(\mathrm{ft})\end{array}$ & $\begin{array}{c}\text { Error } \\
\mathrm{ft})\end{array}$ \\
\hline $7 / 9 / 2003$ & 11.68 & 705.68 & 706.38 & 0.70 & $706.91^{\mathrm{a}}$ & $\mathrm{N} / \mathrm{A}$ & 706.57 & 0.89 & 706.63 & 0.95 \\
\hline $6 / 26 / 2007$ & 9.41 & 703.41 & 703.04 & -0.37 & 704.27 & 0.86 & 703.41 & 0.00 & 703.95 & 0.54 \\
\hline $6 / 3 / 2008$ & 11.06 & 705.06 & 704.43 & -0.63 & 705.14 & 0.08 & 704.24 & -0.82 & 704.89 & -0.17 \\
\hline $7 / 8 / 2008$ & 11.26 & 705.26 & 705.24 & -0.02 & 705.98 & 0.72 & 705.06 & -0.20 & 705.80 & 0.54 \\
\hline $9 / 14 / 2008$ & 11.30 & 705.30 & 706.48 & 1.18 & 706.37 & 1.07 & 706.42 & 1.12 & $706.72^{\mathrm{a}}$ & N/A \\
\hline $\begin{array}{l}\text { Average first four } \\
\text { events }\end{array}$ & 10.85 & 704.85 & 704.77 & -0.08 & N/A & N/A & 704.82 & -0.03 & 705.32 & 0.47 \\
\hline $\begin{array}{l}\text { Average of last four } \\
\text { events }\end{array}$ & 10.76 & 704.76 & 704.80 & 0.04 & 705.44 & 0.68 & 704.78 & 0.03 & N/A & N/A \\
\hline
\end{tabular}

aPeak-stage value occurs during period of significant model instability. 


\section{Summary}

The design model for a set of flood-control projects was evaluated by comparing simulated peak flows for events observed after construction of the projects to the observed peak flows five high-flow events between May 2003 and September 2008 on Boneyard Creek in Champaign-Urbana, Ill., using the as-built version of the SWMM model used to design the projects. Results from four different simulation scenarios were obtained by using two values of a parameter that controls the antecedent moisture condition, in combination with either spatially uniform or spatially variable versions of the precipitation fields, which were developed from rain-gage data distributed by means of Thiessen polygons. At the primary evaluation location, all of the simulated peak discharge values lie within or very near the 95 -percent confidence intervals of the observed peak discharges, and overall, the simulation bias is approximately balanced between overprediction and underprediction. Supplementary comparisons of simulated stage at the primary location and other stage and discharge at nearby gages were also made; these showed the same pattern of differences between observed and simulated values across events but varying biases depending on streamgage and measurement type (discharge or stage). Results from this study show no clear evidence that design model is significantly inaccurate or biased and, therefore, no clear evidence that the modeled flood-control projects in Champaign and on the University of Illinois campus have increased flood stages or discharges downstream in Urbana.

\section{Acknowledgments}

The authors thank several USGS colleagues for assistance with this study: Crystal Prater, for processing of the input and output data and carrying out the SWMM model runs; David Anning, for discussions of discharge uncertainty computations; Kevin Oberg, for insights into streamflow-measurement technologies and their uncertainties; Kevin Johnson, Jim Duncker, Patrick Miller, and many others for scrambling to measure Boneyard Creek's "flash floods" without regard to time of day and heavy precipitation; and Kevin Johnson and Marv Harris, for explanations of the Boneyard Creek streamflow-record computations.

\section{References Cited}

Berns, Clancy and Associates, 1998, Joint agency permit application, Boneyard Creek flood control (Phase 1c Improvements): Urbana, Ill. [variously paged].

Chaille, Brian, and Yen, B.C., 2000, Evaluating watershed changes using double-mass analysis-History in the Boneyard Creek stream gage record: University of Illinois at Urbana-Champaign, Department of Civil and Environmental Engineering, Civil Engineering Studies, Hydraulic Engineering Series No. 67, 48 p.

Draper, N.R., and Smith, Harry, 1981, Applied regression analysis (2d ed.): New York, John Wiley and Sons, 709 p.

Dymond, J.R., and Christian, Ross, 1982, Accuracy of discharge determined from a rating curve: Hydrological Sciences Journal, v. 27, no. 4, p. 493-504.

Fuller, W.A., 1987, Measurement error models: New York, John Wiley and Sons, $440 \mathrm{p}$.

Helsel, D.R., and Hirsch, R.M., 2002, Statistical methods in water resources: U.S. Geological Survey Techniques of Water-Resources Investigations, book 4, Hydrologic analysis and interpretation, chap. A3, $510 \mathrm{p}$.

Herschy, R.W., 1999, Uncertainties in hydrometric measurements, in Herschy, R.W., ed., Hydrometry-Principles and practices ( $2 \mathrm{~d}$ ed.): New York, John Wiley and Sons, $376 \mathrm{p}$.

Huff, F.A., 1990, Time distributions of heavy rainstorms in Illinois: Champaign, Ill., Illinois State Water Survey Circu$\operatorname{lar} 173,18 \mathrm{p}$.

Huff, F.A., and Angel, J.R., 1989a, Frequency distributions and hydroclimatic characteristics of heavy rainstorms in Illinois: Champaign, Ill., Illinois State Water Survey Bulletin $70,177 \mathrm{p}$.

Huff, F.A., and Angel, J.R., 1989b, Frequency distributions of heavy rainstorms in Illinois: Champaign, Ill., Illinois State Water Survey Circular 172, 36 p.

James, W., Huber, W.C., Dickinson, R.E., Pitt, R.E., James, R.C., Roesner, L.A., and Aldrich, J.A., 2003, User's guide to SWMM (9th ed.): Guelph, Ontario, Computational Hydraulics, Inc., 609 p. 
Larson, L.W., and Peck, E.L., 1974, Accuracy of precipitation measurements for hydrologic modeling: Water Resources Research, v. 10, p. 857-863.

Morlock, S.E., 1996, Evaluation of Acoustic Doppler Current Profiler measurements of river discharge: U.S. Geological Survey Water-Resources Investigation Report 95-4218, $37 \mathrm{p}$.

Oberg, Kevin, and Mueller, D.S., 2007, Validation of streamflow measurements made with acoustic Doppler current profilers: Journal of Hydraulic Engineering, v. 133, p. 1421-1432.

Rust Environment \& Infrastructure, 1997, Boneyard Creek Improvement Plan review for the City of Urbana: Oak Brook, Ill., 22 p., apps.
Rust Environment \& Infrastructure, 1998, Boneyard Creek Improvement Plan Phase $1 \mathrm{C}$ review for the City of Urbana: Oak Brook, Ill., 6 p., attachments.

Thiessen, A.H., 1911, Precipitation averages for large areas: Monthly Weather Review, v. 39, p. 1082-1084.

Westcott, N.E., Knapp, H.V., and Hilberg, S.D., 2008, Comparison of gage and multi-sensor precipitation estimates over a range of spatial and temporal scales in the Midwestern United States: Journal of Hydrology, v. 351, p. 1-12.

Wilson, R.D., 1978, An engineer's history of Boneyard Creek in Champaign-Urbana, Illinois (1830 to 1978): Champaign, Ill., Ralph D. Wilson, P.E. \& S.E. [variously paged]. 


 \\ ‡USGS}

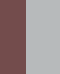

rved Postconstruction Peak Discharges to Evaluate

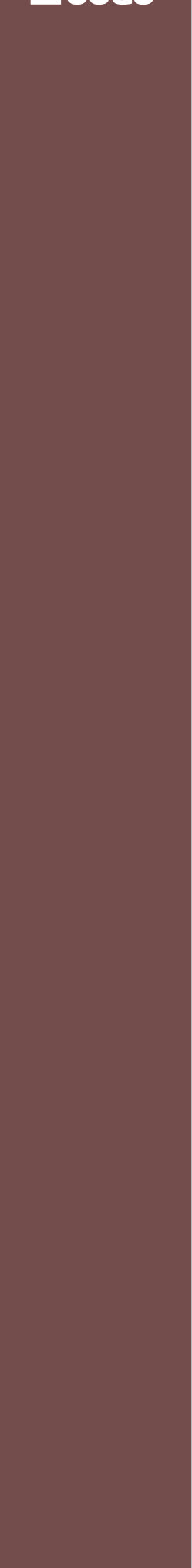

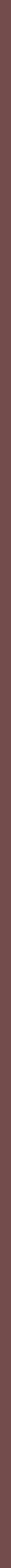

